\title{
INEL BNCT Research Program January/February 1993
}

\author{
Edited by
}

J. R. Venhuizen

Published April 1993

\author{
Idaho National Engineering Laboratory \\ EG\&G Idaho, Inc. \\ Idaho Falls, Idaho 83415
}




\begin{abstract}
This report presents suinmaries for two months of current research of the Idaho National Engineering Laboratory (INEL) Boron Neutron Capture Therapy (BNCT) Program. Information is presented on development and murine screening experiments of low-density lipoprotein, carboranyl alanine, and liposome boron containing compounds. Pituitary tumor cell culture studies are described. Drug stability, pharmacology and toxicity evaluation of borocaptate sodium (BSH) and boronophenylalanine (BPA) are described. Treatment protocol development via the large animal (canine) model studies and physiological response evaluation in rats are discussed. Supporting technology development and technical support activities for boron drug biochemistry and purity, analytical and measurement dosimetry, and noninvasive boron quantification activities are included for the current time period. Current publications for the two months are listed.
\end{abstract}

\title{
DISCLAIMER
}

This report was prepared as an account of work sponsored by an agency of the United States Government. Neither the United States Government nor any agency thereof, nor any of their employees, makes any warranty, express or implied, or assumes any legal liability or responsibility for the accuracy, completeness, or usefulness of any information, apparatus, product, or process disclosed, or represents that its use would not infringe privately owned rights. Reference herein to any specific commercial product, process, or service by trade name, trademark, manufacturer, or otherwise does not necessarily constitute or imply its endorsement, recommendation, or favoring by the United States Government or any agency thereof. The views and opinions of authors expressed herein do not necessarily state or reflect those of the United States Government or any agency thereof. 


\section{CONTENTS}

ACRONYMS AND ABBREVIATIONS $\ldots \ldots \ldots \ldots \ldots \ldots \ldots \ldots \ldots \ldots \ldots$

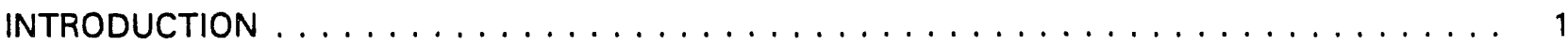

BORON DRUG DEVELOPMENT $\ldots \ldots \ldots \ldots \ldots \ldots \ldots \ldots \ldots \ldots \ldots \ldots$

Carboranyl Alanine and Low-Density Lipoprotein (LDL) Development and Evaluation . . . 1

Boronated Liposome Development and Evaluation $\ldots \ldots \ldots \ldots \ldots \ldots \ldots \ldots \ldots$

Pituitary Tumor Evaluation $\ldots \ldots \ldots \ldots \ldots \ldots \ldots \ldots$

BORON LOCALIZATION SCREENING $\ldots \ldots \ldots \ldots \ldots \ldots \ldots \ldots \ldots \ldots \ldots \ldots \ldots$

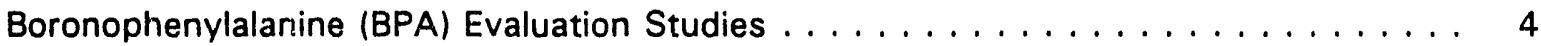

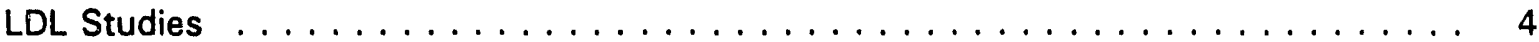

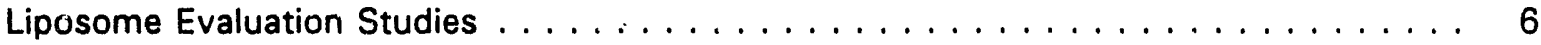

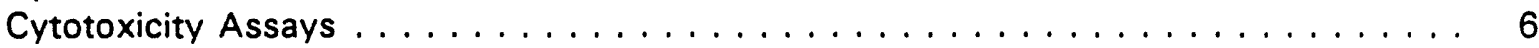

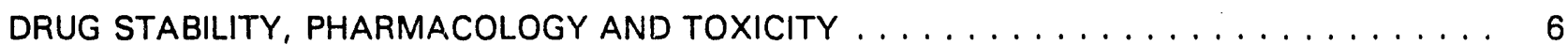

Toxicological Evaluation of Borocaptate Sodium (BSH) $\ldots \ldots \ldots \ldots \ldots$

TREATMENT PROTOCOL DEVELOPMENT $\ldots \ldots \ldots \ldots \ldots \ldots \ldots \ldots \ldots \ldots$

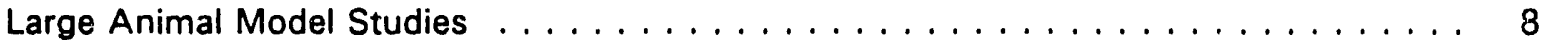

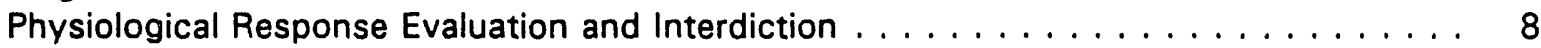

SUPPORTING TECHNOLOGY DEVELOPMENT $\ldots \ldots \ldots \ldots \ldots \ldots \ldots \ldots \ldots \ldots$

Task 1: Biochemistry of BSH and Its Oxidation Products . . . . . . . . . . . . 9

Task 2: Noninvasive Boron Quantification . . . . . . . . . . . . . . . . . . 9

Task 3: Real-Time Measurement Dosimetry Research . . . . . . . . . . . . . . g g

Task 4: Analytical Dosimetry .......................... 9

Task 4A: Macrodosimetric Model Development ................ s

Task 4B: Microdosimetric Model Development . . . . . . . . . . . . . . . 9

Task 4C: Microdosimetric Cellular Response Study . . . . . . . . . . . . . . 9

Task 4D: Dose Treatment Software Development . . . . . . . . . . . . . . 9

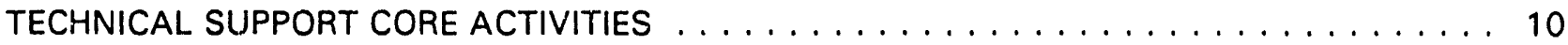

Task 1: ICP-AES Analyses of Boron in Biological Samples . . . . . . . . . . . . . . 10

Task 2: Boron Compound Purity Determinations . . . . . . . . . . . . . . . . 10

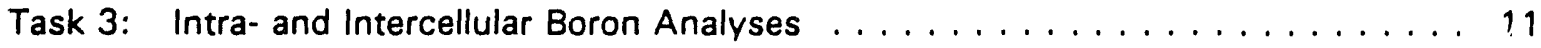

Task 4: Neutron Beam Measurement Dosimetry . . . . . . . . . . . . . . . . 11

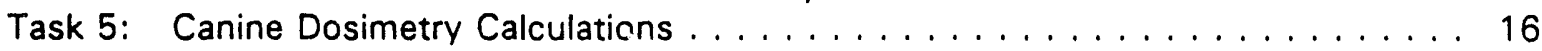

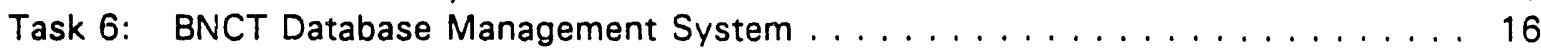

Task 7: Georgia Tech Research Reactor Physics Support . . . . . . . . . . . . . . 16

Task 8: Research Reactor/Accelerator Physics Support . . . . . . . . . . . . . . . 17

Miscellaneous $\ldots \ldots \ldots \ldots \ldots \ldots \ldots \ldots \ldots \ldots \ldots \ldots \ldots \ldots \ldots \ldots \ldots \ldots$ 


\section{FIGURES}

1. AtT-20 cell hormone-conjugate incubation experiment $\ldots \ldots \ldots \ldots \ldots \ldots$

2. Boron levels throughout time (hours) in the indicated tissues $\ldots \ldots \ldots \ldots \ldots$

3. $\mathrm{K}^{+}\left[\mathrm{C}_{2} \mathrm{~B}_{9} \mathrm{H}_{11}\left(\mathrm{CH}_{2}\right)_{15} \mathrm{CH}_{3}\right]^{-}$cytotoxicity when administered in a non-dilute dose to culture medium ......................... 7

4. Teversed phase, ion pair HPLC chromatograms of the new samples (BNCT 473), the reference sample (BNCT 202) and standards of $\mathrm{BSS}^{4 \cdot}$ and $\mathrm{BSSO}^{4 .} \ldots \ldots \ldots \ldots \ldots$

5. Reversed phase ion pair HPLC chromatograms of the Boron Biological samples BNCT 477, BNCT 529 and standards of $\mathrm{BSS}^{4-}$ and $\mathrm{BSSO}^{4} \ldots \ldots \ldots \ldots \ldots \ldots \ldots$

6. ${ }^{1} \mathrm{H}$ NMR of $\mathrm{BNCT} 529$ in $\mathrm{D}_{2} \mathrm{O} \ldots \ldots \ldots \ldots \ldots \ldots \ldots \ldots \ldots \ldots$

7. BMRR: Thermal flux values as a function of depth $\ldots \ldots \ldots \ldots \ldots \ldots$

8. BMRR: Epithermal flux values as a function of depth $\ldots \ldots \ldots \ldots \ldots \ldots$

9. BMRR: Free field neutron spectrum foil measurement $\ldots \ldots \ldots \ldots \ldots \ldots$

10. BMRR: Thermal and epithermal-neutron fluxes as a function of distance in phantom . . 17

11. Fuel element locations for the reconfigured BMRR core $\ldots \ldots \ldots \ldots \ldots$

12. BMRR calculated epithermal-neutron spectrum (case $18 \mathrm{~b}) \ldots \ldots \ldots \ldots$

13. BMRR calculated and measured thermal flux in Lucite cylinder . . . . . . . . . . . . 20

\section{TABLES}

1. In Vivo LDL exposure in mice - B16BL6 melanoma $-\mathrm{LDL}=800 \mu \mathrm{g} \mathrm{B} / \mathrm{kg} \ldots \ldots$

2. In Vitro $\mathrm{LDL}$ exposure $-\mathrm{LDL}=1.12 \mu \mathrm{g} \mathrm{B} / \mathrm{mL} \ldots \ldots \ldots \ldots \ldots \ldots$

3. Oxidation products in BNCT 473, BNCT 477, BNCT 529 and the reference sample

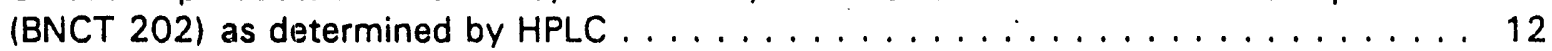

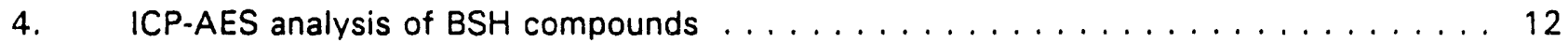

5. CHN combustion analysis of $\mathrm{BSH}$ compounds $\ldots \ldots \ldots \ldots \ldots \ldots \ldots \ldots$

6. BMRR fuel inventory as of July $7,1992 \ldots \ldots \ldots \ldots \ldots \ldots$ 


\section{ACRONYNIS AND ABBREVIATIONS}

\begin{tabular}{|c|c|c|c|}
\hline BMRR & $\begin{array}{l}\text { Brookhaven Medical Research } \\
\text { Reacto; }\end{array}$ & ORSU & Oregon State University \\
\hline BNL . & Brookhaven National & & Phenylalanine arnmonia lyase \\
\hline & Laboratory & SEM & Standard error of mean \\
\hline $\mathrm{BNCT}$ & $\begin{array}{l}\text { Boron Neutron Capture } \\
\text { Therapy }\end{array}$ & TBAS & Tetra bulyl ammorium sulfate \\
\hline & & TLD & Thermoluminescent dosimeter \\
\hline BPA & Boronophenylalanine & & \\
\hline BSH & $\begin{array}{l}\text { Borocaptate Sodium } \\
\left(\mathrm{Na}_{2} \mathrm{~B}_{12} \mathrm{H}_{1} \mathrm{SH}\right)\end{array}$ & & \\
\hline CHNS & $\begin{array}{l}\text { Carbon nitrogen hydrogen } \\
\text { sulfur }\end{array}$ & & \\
\hline $\mathrm{CRH}$ & $\begin{array}{l}\text { Corticotropin releasing } \\
\text { hormone }\end{array}$ & & \\
\hline CT & Computed tomography & & \\
\hline FTIR & $\begin{array}{l}\text { Fourier transformi infrared } \\
\text { spectroscopy }\end{array}$ & & \\
\hline HPLC & $\begin{array}{l}\text { High performance liquid } \\
\text { chromatography }\end{array}$ & & \\
\hline HRP & Horseradish peroxide & & \\
\hline ICP-AES & $\begin{array}{l}\text { Inductively coupled plasma- } \\
\text { atomic emission spectroscopy }\end{array}$ & & \\
\hline ICP-MS & $\begin{array}{l}\text { Inductively coupled plasma- } \\
\text { mass spectrometry }\end{array}$ & & \\
\hline INEL & $\begin{array}{l}\text { Idaho National Engineering } \\
\text { Laboratory }\end{array}$ & & \\
\hline ISU & Idaho State University & & \\
\hline LDL & Low density lipoproteins & & \\
\hline MCNP & $\begin{array}{l}\text { Three-dimensional Monte } \\
\text { Carlo computer code }\end{array}$ & & \\
\hline MRI & Magnetic resonance imaging & & \\
\hline MTT & $\begin{array}{l}\text { 3-[4,5-dimethylthiozole-2-yl]- } \\
\text { 2,5-diphenyltetrazolium } \\
\text { bromide; thiazolyl blue }\end{array}$ & & \\
\hline NMR & Nuclear magnetic resonance & & \\
\hline
\end{tabular}




\section{INEL BNCT RESEARCH PROGRAM JANUARY/FEBRUARY 1993}

\section{INTRODUCTION}

This report contains an overview of progress for the Idaho National Engineering Laboratory (INEL) Boron Neutron Capture Therapy (BNCT) Research Program for January/February 1993, including information on the Research Programs, Technical Support Details, and Miscellaneous Froject Information.

The following sections are the reports from the various investigators about their current research.

\section{BORON DRUG DEVELOPMENT}

\section{Carboranyl Alanine and Low-Density Lipo- protein (LDL) Development and Evaluation}

Inductively coupled plasma-atomic emission spectroscopy (ICP-AES) boron concentration analysis were received for two series of experiments; one in vivo, the other in vitro. Series 18 was a longer term LDL mouse screening with lowered boron dose (due to the extended length of the experiment.) Table 1 presents the results of this work. Mice bearing the B16BL6 melanoma were administered an LDL dose equivalent to $800 \mu \mathrm{g} \mathrm{B} / \mathrm{kg}$ as measured by ICP.
AES. Six mice were sacrificed at each time point, and results are presented as the mean \pm standard error of mean (SEM). These results are consistent with our previous studies in which no selectivity for tumor over blood has been observed. Given the low boron dose, the absolute tumor boron levels are actually quite encouraging, especially at early time points. Once again, essentially no boron was found in brain as would be expected since the LDL particles are too large to cross the blood-brainbarrier. However, the overall lack of selectivity for tumor demonstrated again here suggested that there were significant problems with the tumor/animal model. Two possibilities seem evident; either the B16BL6 melanoma does not over-express the LDL receptor (unlike other tumors) or else the mouse is not an appropriate model for these studies.

In order to help answer this question, in vitro studies were carried out using murine carcinoma (Lewis lung), melanoma (B16BL6) and normal fibroblasts. The latter are expected to have "normal" levels of LDL receptors and are, thus, the control for this experiment. Cells were incubated for 6,12 and 24 hours in the presence of boronated LDL at a boron concentration of $1.12 \mu \mathrm{g} \mathrm{B} / \mathrm{mL}$. After incubation they were spun down and the cell pellet and supernatant were separated for boron measurement. The results of these determinations are presented in Table 2.

Table 1. In vivo LDL exposure in mice - B16BL6 melanoma - LDL $=800 \mu \mathrm{g} \mathrm{B/kg}$.

\begin{tabular}{lcccccc}
\hline & \multicolumn{6}{c}{$\begin{array}{c}\text { tissue boron concentration }(\mu \mathrm{g} / \mathrm{g}) \\
\text { time }(\mathrm{hr})\end{array}$} \\
& 6 & 12 & 18 & 24 & 48 & 72 \\
\hline tumor & $6.1 \pm 2.7$ & $4.6 \pm 1.4$ & $3.6 \pm 0.9$ & $2.3 \pm 0.5$ & $1.1 \pm 0.3$ & $0.8 \pm 0.2$ \\
blood & $7.2 \pm 0.9$ & $5.7 \pm 0.4$ & $4.2 \pm 0.6$ & $3.4 \pm 0.4$ & $1.1 \pm 0.3$ & $0.6 \pm 0.1$ \\
brain & $0.6 \pm 0.2$ & $0.5 \pm 0.1$ & $0.6 \pm 0.1$ & $0.5 \pm 0.1$ & $0.5 \pm 0.1$ & $0.6 \pm 0.2$ \\
\hline
\end{tabular}


Table 2. In vitro $\mathrm{LDL}$ exposure $-\mathrm{LDL}=1.12 \mu \mathrm{g} \mathrm{B} / \mathrm{mL}$.

\begin{tabular}{lccc}
\hline & $6 \mathrm{hr}$ & $12 \mathrm{hr}$ & $24 \mathrm{hr}$ \\
\hline & \multicolumn{3}{c}{ Cell pellet boron concentration $(\mu \mathrm{g} / \mathrm{g})$} \\
murine melanoma & $5.0 \pm 0.5$ & $10.9 \pm 0.7$ & $19.2 \pm .57$ \\
murine carcinoma & $4.8 \pm 0.6$ & $12.8 \pm 1.4$ & $22.0 \pm 2.0$ \\
murine fibroblast & $1.2 \pm 0.3$ & $1.5 \pm 0.3$ & $5.1 \pm 3.2$ \\
& \multicolumn{4}{c}{ supernatant boron concentration $(\mu \mathrm{g} / \mathrm{g})$} \\
murine melanoma & $0.9 \pm 0.1$ & $1.0 \pm 0.2$ & $0.8 \pm 0$ \\
murine carcinoma & $0.9 \pm 0.1$ & $1.3 \pm 0.7$ & $0.9 \pm 0.2$ \\
murine fibroblast & $0.9 \pm 0.1$ & $1.0 \pm 0.3$ & $1.6 \pm 0.5$ \\
\hline
\end{tabular}

Several conclusions are immediately apparent. The melanoma and carcinoma behave identically toward the boronated $L D L$, suggesting that both cell lines do over-express the LDL receptor as compared to murine fibroblasts. (The 24 hour fibroblast point has a large relative SEM caused by one major outlyer.) Noteworthy is the increasing boron content over time in both transformed cell lines. Linear uptake vs. time for boronated LDL has previously been observed for $\mathrm{CHO}$ and $\mathrm{V}-79$ cells, and is believed to be related to the nearly complete replacement of cholesterol ester with carborane ester. In the natural LDL, internalized cholesterol ester from the LDL core acts as a negative feedback signal to suppress receptor-mediated uptake, but with boronated LDL the signal is missing and receptor-mediated uptake is linear with time. Also noteworthy is the total boron content of both cell lines at 24 hours. Given the very small administered boron dose, a 24 hour value of $\sim 20 \mathrm{ppm}$ boron is very substantial. By comparison, when $\mathrm{CHO}$ cells were incubated at a boron concentration of 23 $\mu \mathrm{g} / \mathrm{mL}$ and then measured for boron by the prompt gamma technique, $240 \mathrm{ppm}$ boron was found. The present values are proportionally $30 \%$ greater, a not unreasonable value considering that previously demonstrated in vitro uptake is more efficient at lower incubation concentrations. In all but one case, the supernatant boron concentration is within experimental error of starting incubation value.

These data suggest an answer to the question raised by the in vivo studies. It appears that the melanoma cell line is not special and expresses the expected elevated LDL receptor activity. The University of California, San Francisco researchers thus believe that the problem lies in the use of mice as the test animal. Although the mouse LDL receptor recognizes the human Apo B-100 protein and internalizes boronated LDL by receptor-mediated endocytosis, the mouse lipoprotein system differs from the human in one critical respect; the mouse relies primarily on high density lipoprotein to obtain its required cholesterol. Thus normal mice are not the optimum model system for testing the selectivity of boronated LDL. In consultation with researchers at Washington State University (WSU), the decision was made to switch to a nude mouse bearing a human glioma line for future experiments. The U87MG line has been acquired by WSU and in vitro testing will begin in April, with in vivo testing beginning soon thereafter if all goes as planned.

New batches of boronated LDL were sent to WSU in January and February.

\section{Boronated Liposome Development and Evaluation}

Compound Development: Work has continued on the large scale production and purification of the amine compound $\mathrm{Na}_{3}\left[\mathrm{~B}_{20} \mathrm{H}_{17} \mathrm{NH}_{3}\right]$.

Crystals of $\left[\left(\mathrm{CH}_{3}\right)_{4} \mathrm{~N}_{3}\left[\mathrm{~B}_{20} \mathrm{H}_{17} \mathrm{NH}_{3}\right]\right.$ suitable for crystallographic analysis have been grown from water and from water/ethanol, and $x$-ray data has been collected. The refinement of the $x$ ray data has confirmed the structure proposed for this species, but difficulties prevented a completely satisfactory solution to the data. 
The production of more suitable crystals employing different cations is being explored.

A recent goal in compound development has been the synthesis of boron containing phospholipid-like molecules for incorporation within liposomes. The first compound developed toward this goal contained one long chain alkyl group, $\mathrm{K}\left[\mathrm{C}_{2} \mathrm{~B}_{9} \mathrm{H}_{11}\left(n-\mathrm{C}_{18} \mathrm{H}_{33}\right)\right]$, and was successfully embedded in liposomes and produced promising biodistribution results. This species may, however, adversely affect the stability of the liposomes or be easily leeched out of the bilayer. Ultimately, the desired compound would contain two long alkyl groups in order to more closely mimic the structure of the phospholipids used improve its packing within the lipid bilayer, and prevent it from being stripped from the liposome prematurely.

The first such species has been synthesized by a combination of published methods. The stoichiometric iodination of 0 -carborane produces $9,12-\mathrm{C}_{2} \mathrm{~B}_{10} \mathrm{H}_{10} \mathrm{I}_{2}$ in high yield. This dilodide is alkylated by Grignard reagents in the presence of a small amount of a palladium catalyst. When stearyl magnesium bromide was used as the alkylating agent the product obtained was 9,12- $\left(\mathrm{C}_{18} \mathrm{H}_{37}\right)_{2} \mathrm{C}_{2} \mathrm{~B}_{10} \mathrm{H}_{10}$. The yield of this reaction has been disappointing so far (ca. $30 \%$ ), but it offers a direct route to the desired species, and it may be possible to recover unreacted starting material. The distearyl carborane may be easily degraded to produce an ionic head group for the "borolipid". The synthesis of $\left[5,6-\left(\mathrm{C}_{18} \mathrm{H}_{37}\right)_{2} \mathrm{C}_{2} \mathrm{~B}_{9} \mathrm{H}_{10}\right]$ is in progress.

Liposome Encapsulation and Development: Liposomes have been prepared and sent to WSU for murine screenings using the Lewis Lung carcinoma tumor line. The vesicles contained $K\left[\mathrm{C}_{2} \mathrm{~B}_{9} \mathrm{H}_{1},\left(n-\mathrm{C}_{16} \mathrm{H}_{33}\right)\right]$ embedded within the liposome bilayer membrane as previously prepared, but at a higher concentration. Additionally, a sample of this species dissolved in buffer is being sent to compare the behavior of the unencapsulated species with that of the liposomes.

Tissue samples from three murine biodistribution experiments performed at Vestar, Inc., using the EMT6 mammary adenocarcinoma, have been analyzed. The first experiment examined the biodistribution of $\left[\mathrm{B}_{10} \mathrm{H}_{8} \mathrm{NH}_{3}\right]$. This species was not expected to exhibit high tumor retention but was investigated for comparison with $\left[\mathrm{B}_{20} \mathrm{H}_{17} \mathrm{NH}_{3}\right]^{3}$. The injected dose (single bolus in the tail vein) was $146 \mu \mathrm{g} \mathrm{B} \mathrm{(8} \mathrm{mg} \mathrm{boron} / \mathrm{kg}$ body weight). As expected, the liposomes delivered a good initial boron dose to the tumor (21 ppm at 6 hours). The boron was not retained by the tumor, however, steadily decreasing to $4.1 \mathrm{ppm}$ at the end of the 48 hour experiment. All other tissues examined (blood, liver, and spleen) also decreased to less than $4 \mathrm{ppm}$ boron at 48 hours. These results confirm our hypothesis that the amine functionality itself is not the cause of the high tumor uptake and retention observed for liposomal $\mathrm{Na}_{3}\left[\mathrm{~B}_{20} \mathrm{H}_{17} \mathrm{NH}_{3}\right]$.

Another experiment reexamined the biodistribution of liposomal $\mathrm{Na}_{3}\left[\mathrm{~B}_{20} \mathrm{H}_{17} \mathrm{NH}_{3}\right]$. The injected dose was $262 \mu \mathrm{g} \mathrm{B}(14 \mathrm{mg}$ bo$\mathrm{ron} / \mathrm{kg}$ body weight). The biodistribution in the blood and tumor was analogous to that observed in the previous experiment with this species, although the tumor uptake was somewhat increased due to the higher injected dose. The tumor values were $29 \mathrm{ppm}$ ( 6 hours), 41 ppm (16 hours), 59 ppm (30 hours), and 46 ppm (48 hours). Blood boron levels began at $44 \mathrm{ppm}$ and dropped quickly, finishing at 3 ppm. The biggest difference between this experiment and the earlier examination was in the liver and spleen boron concentrations. While before the liver and spleen values dropped below those of the tumor by the end of 48 hours, in the present case they started very high and decreased only slightly; the final values were $68 \mathrm{ppm}$ for the liver and $65 \mathrm{ppm}$ for spleen. The size and integrity of these liposomes are under investigation in an attempt to explain this higher uptake.

The biodistribution of $\mathrm{Na}_{3}\left[\mathrm{~B}_{20} \mathrm{H}_{17} \mathrm{NH}_{3}\right]$ as a free species were also examined. The amount injected was $175 \mu \mathrm{g} \mathrm{B}(10 \mathrm{mg}$ boron $/ \mathrm{kg}$ body weight) dissolved in buffer solution (not encapsulated in liposomes). Such an administration generally results in a very brief circulation time for the borane anion. The blood boron level was only 3 ppm at 6 hours and quickly dropped below $1 \mathrm{ppm}$. This short circulation lifetime usually prevents tumor uptake approaching that of liposomes, however, some tumor selectivity was observed. Boron concentrations in the tumor began at about $8 \mathrm{ppm}$ at 6 and 16 hours before decreasing to $6 \mathrm{ppm}$ at 30 hours and 4 $\mathrm{ppm}$ at 48 hours. Liver uptake of boron was approximately twice that of tumor, starting at 
$13 \mathrm{ppm}$ at 6 hours and steadily decreasing to $8 \mathrm{ppm}$ at 48 hours.

One set of liposomes has been prepared and sent to WSU for murine screenings using the Lewis Lung carcinoma tumor line. The vesicles contained $\mathrm{K}_{0}\left[\mathrm{C}_{2} \mathrm{~B}_{9} \mathrm{H}_{11}\left(n-\mathrm{C}_{16} \mathrm{H}_{33}\right)\right]$ embedded within the liposome bilayer membrane and $\mathrm{Na}_{2} \mathrm{~B}_{10} \mathrm{H}_{9} \mathrm{NCO}$ encapsulated within the aqueous core. Both of these species have heen investigated individually and have shown promising results. The current experiment is to determine if the tumor boron accumulation of the embedded and encapsulated species is cumulative.

\section{Pituitary Tumor Evaluation}

Pituitary tumor cells (AtT-20) have been exposed to irradiation in the $1 \mathrm{MW}$ TRIGA reactor at Oregon State University (ORSU) at one third power for ten minutes after incubation with corticotropin releasing hormone (CRH) conjugated carborane. The gamma dose at this power and time at our in vitro sample holder was approximately $260 \mathrm{cGy}$, with a thermal neutron fluence of approximately $1.3 \times 10^{13} \mathrm{n}$ $\mathrm{cm}^{2}$. This gives a gamma ray to thermal neutron ratio of about $2.1 \times 10^{-11} \mathrm{cGy} /\left(\mathrm{n}-\mathrm{cm}^{-2}\right)$. Either $\mathrm{CRH}$ unconjugated to our carborane cage, at $10^{-8} \mathrm{M}$ or $\mathrm{CRH}$-carborane conjugate at the same concentration were incubated with the AtT-20 cells for either 19 or 3 hours. Cells were washed, exposed to neutrons, washed, and diluted so that approximately 300 cells were plated in 6-well culture dishes. Cell viability was assessed with colony counting after eight days of cell growth (cells were washed, fixed with formalin, and stained with Geimsa). "Control" cells were treated with $\mathrm{CRH}$ and taken through the experimental procedure, but were not exposed to the neutrons. All values are means plus or minus one standard deviation of six wells. Wells with control cells had approximately 50 colonies after eight days. Cells exposed to $\mathrm{CRH}$ and unconjugated carborane cage for three hours also had approximately 50 colonies per well. However, when these cells were pre-exposed to $\mathrm{CRH}$-carborane cage conjugate for three hours, only twelve colonies were counted, consistent with a significant BNCT effect $(p<.0001)$. Similar results are observed when AtT-20 cells are preincubated with $\mathrm{CRH}$ and carborane cage for 19 hours, followed by irradiation at similar time and power. The results of this preliminary studies are shown in Figure 1. These results strongly suggest that $\mathrm{CRH}$-conjugated carborane cage is selectively targeted to AtT-20 cells via the $\mathrm{CRH}$ receptors, and that subsequent neutron expose significantly decreases cell colony formation in vitro. This is the first evidence that releasing hormones can selectively target pituitary cells for BNCT. Further studies are ongoing to optimize the cell handling and culture conditions of these in vitro experiments. Moreover, new hormone carriers are being tested for their effectiveness in applying BNCT to breast cancer, prostate cancer, meningiomas, small cell carcinomas of the lung, pancreas cancer, and cancer of the adrenal cortex.

\section{BORON LOCALIZATION SCREENING}

\section{Boronophenylalanine (BPA) Evaluation Studies}

B16-BL6 melanoma bearing BDF mice were injected with phenylalanine ammonia-lyase (PAL) to enzymatically reduced blood levels of free tyrosine and phenylalanine. Mice were then injected, four hours post-PAL injection, with BPA. Mice were sacrificed at 3, 6, 12 and 24 hours following BPA injection. Tissues taken at the time of necropsy were: blood, tumor, liver, kidney, spleen, brain, skin and muscle. Samples were sent to INEL for analy. sis. Boron levels were found to be maximum in the tumor at three hours, having an average concentration of $14.01 \mu \mathrm{g} / \mathrm{g}$ (Figure 2). Tumor boron levels in one mouse reached $20.9 \mu \mathrm{g} / \mathrm{g}$. At three and six hours, tumor-to-blood ratios were determined to be 5.9:1 and 7.2:1, respectively.

Tumor levels of free phenylalanine and tyrosine are being determined.

Future BPA studies are being terminated due to funding constraints.

\section{LDL Studies}

The following compounds have been received from the University of California, San Francisco for in vivo screenings using BDF mice bearing B16-BL6 melanoma: 
Cell viability after eight days of cell growth.

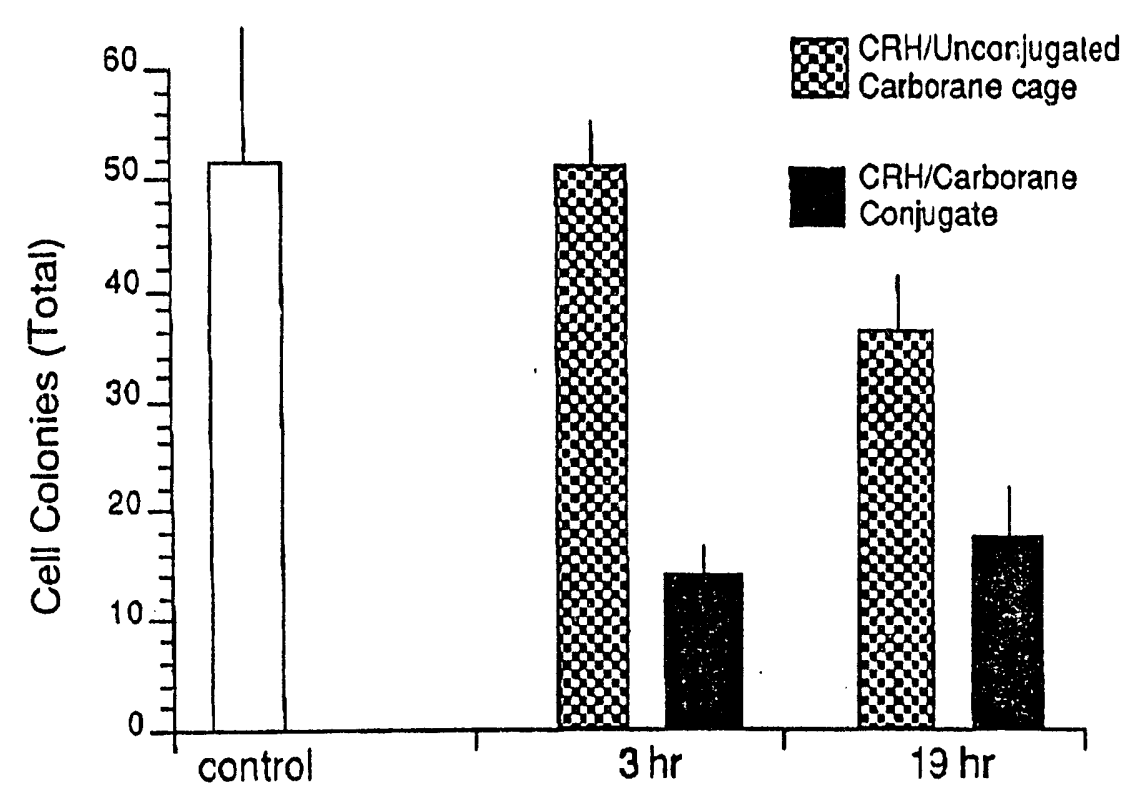

Figure 1. AtT-20 cell hormone-conjugate incubation experiment.

BPA-PAL in vivo studies, six mice per time point.

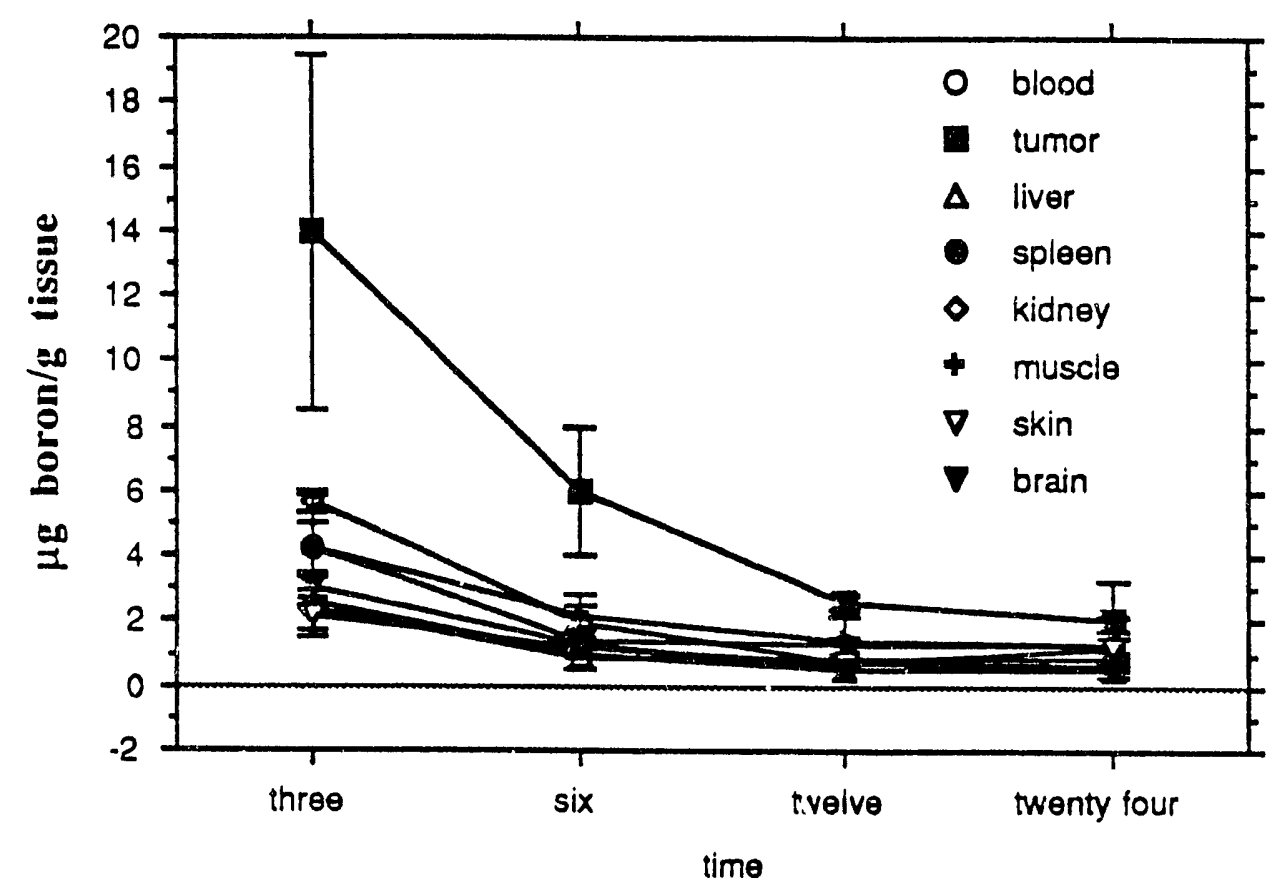

Figure 2. Boron levels throughout time (hours) in the indicated tissues. 
LW-1-55: Tissue and blood samples have been sent to INEL for analysis. Results are pending.

LW-1-59: Tissue and blood samples have'been sent to INEL for analysis. Results are pending.

\section{Liposome Evaluation Studies}

The following compounds were screened in vitro for boron uptake using murine Lewis Lung carcinoma, murine B15-BL6 melanoma, rat glioma and normal murine mammary fibroblast:

$\underline{\mathrm{Na}}_{3} \underline{\mathrm{B}}_{20} \underline{H}_{18}$ : Cell pellets and supernatant samples have been sent to INEL for analysis. Results are pending.

$\underline{\mathrm{K}}+\mathrm{C}_{2} \underline{\mathrm{B}}_{9} \underline{\mathrm{H}}_{1}, \mathrm{CH}_{2} \mathrm{~L}_{15} \mathrm{CH}_{3} \mathrm{~L}$ lembedded in lipid bilaver) and $\mathrm{Na}_{3} \mathrm{~B}_{20} \mathrm{H}_{12}$ (encapsulated): Cell pellets and supernatant samples have been sent to INEL for analysis. Results are pending.

$\underline{\mathrm{K}}^{+}\left[\mathrm{C}_{2} \underline{\mathrm{B}}_{9} \mathrm{H}_{11} \mathrm{CCH}_{2} \mathrm{~L}_{15} \mathrm{CH}_{3} \mathrm{~L}\right.$ : Cell pellets and supernatant samples have been sent to INEL for analysis. Results are pending.

The following liposome encapsulated compounds were screened in vivo for boron uptake

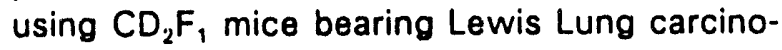
ma:

$\mathrm{Na}_{3} \underline{B}_{20} \underline{H}_{19}$ i Tissue and blood samples have been sent to iNEL for analysis. Results are pending.

The following liposome encapsulated compounds were screened in vivo for boron uptake using C57 mice bearing Lewis Lung carcinoma. WSU researchers have determined that the $\mathrm{C} 57$ mouse model is optimal for tumor growth.

$\underline{\mathrm{K}}+\mathrm{C}_{2} \underline{\mathrm{B}}_{9} \mathrm{H}_{11} \mathrm{CCH}_{2} \mathrm{~L}_{16} \mathrm{CH}_{3} \mathrm{~L}$ lembedded in lipid bilaver) and $\mathrm{Na}_{3} \mathrm{~B}_{20} \mathrm{H}_{1}$ (encapsulated): Tissue and blood samples have been sent to INEL for analysis. Results are pending.

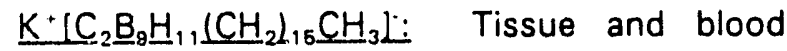
samples have been sent to INEL for analysis. Results are pending.

$\mathrm{K}^{+}\left[\mathrm{C}_{2} \underline{B}_{9} \underline{H}_{11} \mathrm{CCH}_{2} \mathrm{~L}_{15} \mathrm{CH}_{3}\right]^{\circ}$ lembedded in lipid bilaver) and $\mathrm{Na}{ }_{2} \underline{B}_{10} \mathrm{H}_{8} \mathrm{NCO}$ (encapsulated): Tissue and blood samples have been sent to INEL for analysis. Results are pending.

\section{Cytotoxicity Assays}

The following liposome encapsulated compounds have been tested in vitro for cytotoxic effects. Serial dilutions ranging from neat (pure) to $1: 1000$ were used. Growth was determined by 3-[4,5-dimethylthiozole-2-yl]2,5-diphenyltetrazolium bromide; thiazolyl blue (MTT) analysis or hemocytometry.

$\mathrm{Na}_{3} \underline{B}_{20} \underline{H}_{19}$ : Compound has been determined to be noncytotoxic.

$\mathrm{K}^{+} \mathrm{C}_{2} \underline{\mathrm{B}}_{9} \mathrm{H}_{11} \mathrm{CCH}_{2} \mathrm{~L}_{15} \mathrm{CH}_{3} \mathrm{~L}$ lembedded in lipid bilaver) and $\mathrm{Na}_{3} \mathrm{~B}_{20} \mathrm{H}_{12}$ (encapsulated): Compound has been determined to be noncytotoxic.

$\mathrm{K}^{+}\left[\mathrm{C}_{2} \underline{B}_{9} \underline{H}_{11}\left(\mathrm{CH}_{2}\right)_{16} \underline{\mathrm{CH}}_{3} \mathrm{~L}\right.$ : Compound has been determined to be cytotoxic at lower dilutions (Figure 3).

DRUG STABILITY, PHARMACOLOGY AND TOXICITY

\section{Toxicological Evaluation of Borocaptate Sodium (BSH)}

Idaho State University (ISU) researcher's current working hypothesis concerning BSH's acute effects on the cardiovascular system is that this drug initially elicits a positive inotropic effect, peripheral vaseconstriction and myocardial sensitization. ISU researchers think the transient increase in cardiac output reflects an increase in left ventricular contractility that is soon overcome by an increasing total peripheral resistance (elevated afterload). Increasing oxygen demand, coupled with coronary artery vasoconstriction and cardiac sensitization are thought to mimic ischemic heart disease, decrease cardiac output and predispose the heart to arrhythmogenesis. Following large BSH doses, it is hypothesized that sensitization of the myocardium and/or myocardial ischemia precipitates ventricular fibrillation, cardiovascular collapse and death. Preliminary observatioris indicate that lethal doses of $\mathrm{BSH}$ do induce a massive vasoconstriction of the coronary artery. ISU researchers also hypothesize 


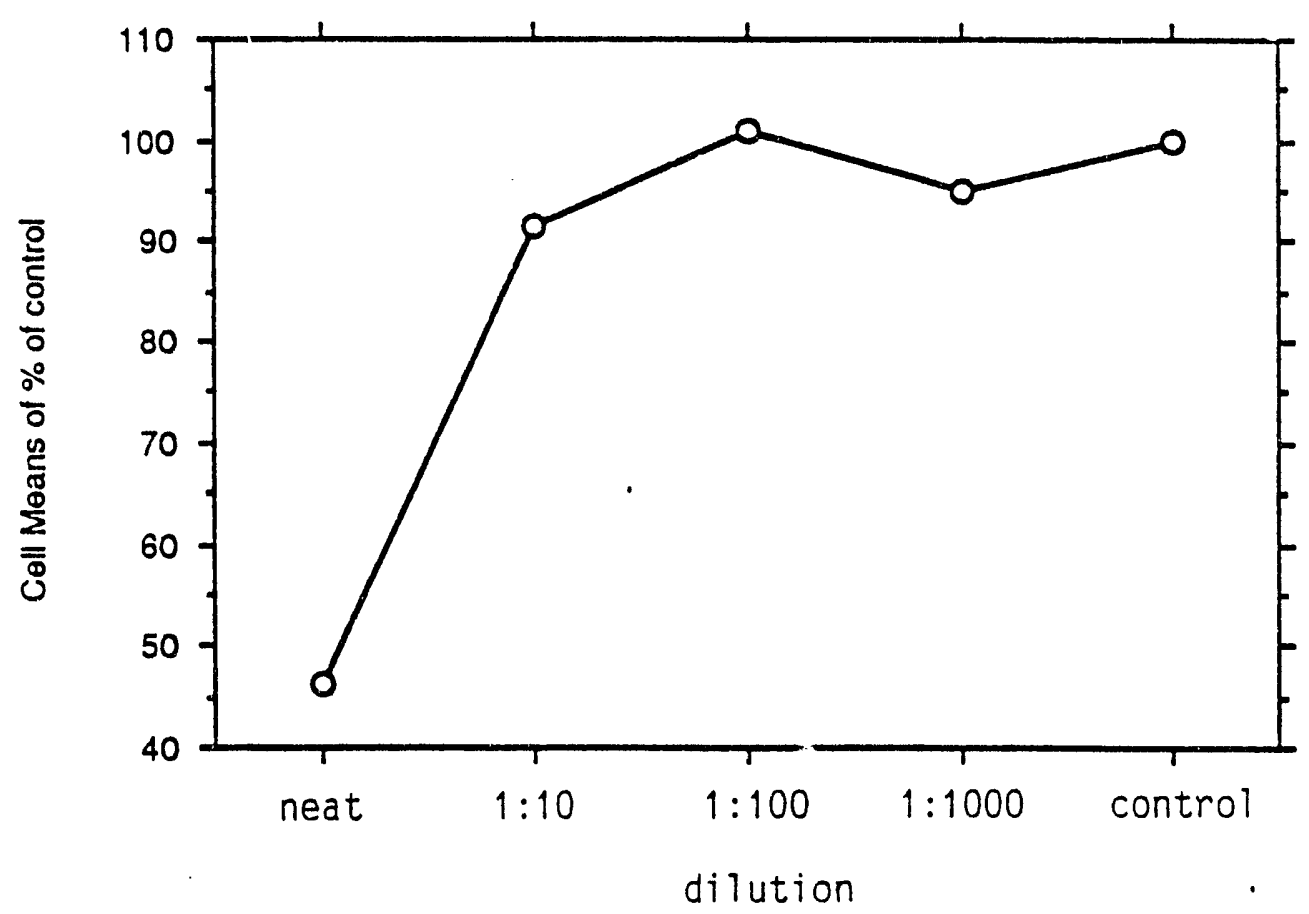

Figure 3. $\mathrm{K}^{+}\left[\mathrm{C}_{2} \mathrm{~B}_{9} \mathrm{H}_{11}\left(\mathrm{CH}_{2}\right)_{15} \mathrm{CH}_{3}\right]^{\cdot}$ cytotoxicity when administered in a non-dilute dose to culture medium.

that slightly lower doses, while not eliciting ventricular fibrillation, cause a large increase in total peripheral resistance, and that the elevation of total peripheral resistance is at least partially due to constriction of hepatic and renal arterial beds. According to our hypothesis, poor perfusion of these organs leads to necrosis, organ failure and death with 2-4 days. Preliminary measurement of renal blood flow indicates that non-lethal doses of BSH are associated with a transient $30 \%$ reduction of renal blood flow, and that doses of BSH that typically cause death within 2-4 days are associated with a massive $(90 \%)$ and prolonged reduction in renal blood flow. Experiments are currently underway to determine if a combination of dobutamine (inotropic agent), nitroprusside (Vasodilator) and saline (fluid loading) can reverse the $\mathrm{BSH}$-induced renal vasoconstriction while maintaining adequate blood pressure and tissue perfusion. If so, the antidotal value of the therapy will be evaluated.
The working hypothesis also predicts that any activation of the sympathetic autonomic nervous system could potentiate $\mathrm{BSH}$-induced arrhymogenesis. If correct, this could explain the observation that instrumenting rats for measurement of physiological function markedly increases the lethality of BSH. To test this portion of the hypothesis, ISU researchers are pretreating instrumented animals with $\beta$-adrenergic and $\alpha$-adrenergic antagonists prior to administration of BSH. If cardiac sensitization is a significant factor, then these pretreatments should reduce the lethality of BSH. 


\section{TREATMENT DEVELOPMENT

\section{Large Animal Modei Studies}

Pharmacokinetics: WSU aided Brookhaven National Laboratory (BNL) in January with preliminary BPA-fructose pharmacokinetics studies. Four dogs were infused, euthanized and tissues were collected at WSU for boron analysis. Blood and tissues were divided and sent to Jeff Coderre at BNL and Bill Baver at INEL.

WSU also aided BNL with irradiation of BPAfructose dogs. Five Beagles were irradiated the first part of February. The infusion was over 15 minutes, followed by a two hour wait and then a 60 minute irradiation.

Normal Tissue Tolerance (Neutron Irradiation): New research dogs have arrived and all baseline work is done. This includes physical exams, blood work, computed tomography (CT) and magnetic resonance imaging (MRI) scans.

One dog, at $25 \mathrm{ppm}$ and $19 \mathrm{~Gy}$, had his six month post irradiation checkup. No abnormalities were seen on the CT or NRI scans.

Three dogs, at $25 \mathrm{ppm}$ and $23 \mathrm{~Gy}$, had their 12 month post irradiation checkups. The $C T$ and MRI scans revealed no changes. Afterwards the dogs were euthanized and necropsied.

Five dogs were irradiated during February. Three dogs were done at $70-100 \mu \mathrm{g} / \mathrm{kg}$ boron and irradiated at 36-42 Gy. Two dogs were at $40-60 \mu \mathrm{g} / \mathrm{kg}$ boron and irradiated at 30-34 Gy.

All remaining dogs that have been irradiated are clinically normal.

Spontaneously-Occurring Brain Tumor Dogs: "Lady" Stair (\$35447-171), a five year old spayed female Chocolate Labrador Retriever, was presented to WSU on February 2, 1993 for sudden onset of seizures. The CT scan revealed a suspicious area, but on MRI there was no evidence of a lesion. "Lady" was sent home with medications.
"Crystal" Ard (\#35447-164), a nine year old spayed female Malamute, was first presented to WSU January 1992 for onset of seizures. Her owners elected to maintain "Crystal" on medication. "Crystal" returned to WSU February 1993 for reexamination. Surgery was performed to remove the tumor. If "Crystal" is clinically stable, she will undergo irradiation treatment the week of March 22, 1993.

"Dudly" Fiset (\#35447-151), an eight year old castrated male Golden Retriever, had his two year post treatment checkup. Neurologically everything is great and the only problem is that "Dudley" has gained his weight back.

"Brandy" Hoff (\#35447-94), an eight year old spayed female Golden Retriever, is also doing great. She was having trouble with hair loss, but that has cleared up and all her hair has regrown.

\section{Physiological Response Evaluation and Interdiction}

Cellular Basis of Central Nervous System Iniury: BNCT vs. Photon: 60 Gy Irradiation: Under the accelerated dose program, the pilot irradiations from $7.5 \mathrm{MW}$-min up to $20 \mathrm{MW}$-min have been performed. Three Fischer 344 rats were injected with glutathione ethyl ester and BSH and irradiated at the Brookhaven Medical Research Reactor (BMRR) with the collimator provided by INEL. The estimated blood boron levels were about $110 \mathrm{ppm}$. Two rats received $15 \mathrm{MW}$-min and one at $20 \mathrm{MW}$-min. The rat receiving $20 \mathrm{MW}$-min died nine days after irradiation from a nasopharyngeal radiation problem including severe inflammation of the oral mucosa. There was a $27 \%$ decrease in body weight. One of the rats at $15 \mathrm{MW}$-min went through a similar syndrome of weight loss and facial swelling but recovered after administration of intravenous amino acids/vitamins/dextrose. (Rats irradiated in November 1992 with 7.5 and $10 \mathrm{MW}$-min went through a transient weight loss at about 45-50 days.) The limiting tissue appears to be the oral mucosa, not the intestinal epithelium. The estimated dose delivered to the endothelium for the $15 \mathrm{MW}$-min exposure was about 45 (GyxRelative biological effectiveness).

Using Monte Carlo simulations, the physicist at BNL has designed a better collimator, which is being fabricated now. This new collimator will 
reduce the whole-body dose by a factor of two.

Therapeutic Ratio in RAT 9L Gliosarcoma: BNCT vs. Photons: Fourteen animals were used in this experiment. There were three experimental groups; control, medium and 9LGS. All of the tumor implant animals received $10^{4}$ 9L-GS tumor cells into the left striatum using the procedure described by Coderre et. al., (1992). The animals were treated with horseradish peroxide ('HRP) and perfused 14 days post-impiantation. All of the tissue has been processed and data acquisition is complete. Sta:istical anaiysis is $100 \%$ complete.

Clinical Dose Time Fractionation Regime Using Single vs. Two or Mor Fractions: BNCT Fractionation Study: Eight brains have been processed for HRP histochemistry. Approximately $75 \%$ of the tissue has been processed and the data analysis is proceeding.

Canine BNCT Study: Seven dog brains were received. To date, all of this tissue has been sectioned; approximately $50 \%$ has undergone data acquisition. This is progressing slowly due to the lack of funding.

Canine BNCT Study Part II: Two containers of tissue have been received; they appear to contain eight brains. The tissue is waiting for processing. This is progressing slowly due to the lack of funding.

\section{SUPPORTING TECHNOLOGY DEVELOPMENT}

\section{Task 1: Biochemistry of BSH and Its Oxi- dation Products}

No progress to report.

\section{Task 2: Noninvasive Boron Quantification}

University of Utah researchers are beginning to track breakdown of the blood-brain-barrier in the experimental canine gliosarcoma model. This is done by measuring gadolinium penetration as indicated by enhancement of tumor water proton spin-lattice (T1) relaxation. As the barrier breaks down with tumor maturation, greater enhancements occur. These findings could guide in planning early BSH uptake experiments, with single or fractionated doses.

Drs. Tang and Schweizer are beginning to put together hardv/are and software permitting ${ }^{10} \mathrm{~B}$ detection via attached protons. This so-called indirect detection might permit imaging of ${ }^{10} \mathrm{~B}$ enriched BNCT candidate drugs and thereby reduce concern about ${ }^{11} B$ imaging of natural isotopic species which might compete for tumor tissue binding sites prior to neutron irradiation.

Task 3: Rsal-Time Measurement Dosimetry Research

No progress to report.

Task 4: Analytical Dosimetry

Task 4A: Macrodosimetric Model Development

No progress to report.

Task 4B: Microdosimetric Model Development

No progress to report.

Task 4C: Microdosimetric Cellular Response Study

No progress to report.

Task 4D: Dose Treatment Software Development

The contract with Montana State University (MSU) was put in place January 1993. Four graduate research assistants and $1 / 2$ faculty member are working with INEL researchers during the spring semester with the following tasks:

1. integrated bnct_edit/rtt_mc execution environment,

2. $\mathrm{QSH}$ image format adaptation,

3. splined surface intersection detection,

4. transformation of bnct_edit normalized coordinate space to modeling space, 
5. integrated render option, and

6. miscellaneous repairs and completions.

MSU researchers put bnct_edit under the Revision Control System to control and manage access to the INEL coding. As noted in the previous monthly report, an improved contouring feature was developed and this is currently being integrated into bnct_edit.

\section{TECHNICAL SUPPORT CORE ACTIVITIES}

\author{
Task 1: ICP-AES Analyses of Boron in \\ Biological Samples

$\begin{array}{ll}\text { Samples Received } & =2692 \\ \text { Samples Prepared for Analysis } & =\sim 1990 \\ \text { Samples Analyzed } & =\sim 2515 \\ \text { Backlog: } & =\sim 4400 \\ \text { Awaiting Preparation } & =\sim 1380 \\ \text { Blood, Liver, Spleen, and Tumor } & \\ \text { Other-Brain, Skin, Muscle, } & =\sim 2200 \\ \text { Kidney, etc. } & =\sim 244 \\ \text { Prepared, Awaiting Analysis } & \end{array}$

Currently, the Fisons/ARL Model 3520 ICP-AES is down. The RF coil has been burned and a new one is on its way from Switzerland.

Samples awaiting preparation have been broken into two groups. Recently, the WSU researchers have been sending all of the samples from all mice in each screening. INEL priority is to only do the blood, tumor, kidney and spleen samples from the screenings using boronated liposomes. The "other" tissue samples for these screenings will only be done if requested. Some spleen and liver samples are also from early screenings (i.e. screenings $1-10$ ) and also will not be analyzed unless requested to do so.

Freezer space is currently at a premium and all samples received prior to October 1, 1991 are to be discarded.

Analyses were also conducted to determine the elemental composition of materials to be used in the WSU reflected scalp irradiations. Analyses included ICP-AES, $x$-ray fluorescence, and carbon nitrogen hydrogen-sulfur (CHNS).
Task 2: Boron Compound Purity Determinations

Two separate shipments of chemicals were received for analysis from Boron Biologicals. The first batch, $\mathrm{Na}_{2}{ }^{10} \mathrm{~B}_{12} \mathrm{H}_{1}, \mathrm{SH},\left(\mathrm{Na}_{2}{ }^{10} \mathrm{BSH}\right)$ contained a total of $4 \mathrm{~g}$ packaged in $1 \mathrm{~g}$ ampules. One vial was opened for the purity investigations, this vial represented the Boron Biological Lot number 010693, the assigned INEL inventory number was BNCT 473. At the same time, a portion of the sample from this vial was archived. The second batch included $60 \mathrm{~g}$ packager. in $1 \mathrm{~g}$ ampules of $\mathrm{Na}_{2} \mathrm{~B}_{12} \mathrm{H}_{1}, \mathrm{SH}$, $\left(\mathrm{Na}_{2} \mathrm{BSH}\right)$ and 25 each of $1 \mathrm{~g}$ ampules of $\mathrm{Na}_{2}{ }^{10} \mathrm{~B}_{12} \mathrm{H}_{1} \mathrm{SH},\left(\mathrm{Na}_{2}{ }^{10} \mathrm{BSH}\right)$. One vial of $\mathrm{Na}_{2} \mathrm{BSH}$ (BNCT 477) was opened for the purity investigations. This vial represented the Boron Biologicals Lot number KB136A2. Again a portion material in this vial was archived. One vial of $\mathrm{Na}_{2}{ }^{10} \mathrm{BSH}$ (BNCT 529) representing Boron Biologicals Lot number KB146 was also opened for the purity investigations. The samples received from Boron Biological were subjected to the routine INEL tests for purity analysis, high performance liquid chromatography (HPLC), nuclear magnetic resonance spectroscopy (NMR), CHNS analysis, ICP-AES and fourier transform infrared spectroscopy (FTIR).

HPLC Analysis: Chromatography was performed on a $250 / 1 / 4 / 3 \mathrm{~mm}$ column packed with type 120-5, $C_{18}, 5 \mu \mathrm{m}$ particles of Nucleosil\%. The mobile phase was approximately a $48 \%$ methanol - $52 \%$ water solution with $5 \mathrm{mM}$ tetra bulyl ammonium sulfate (TBAS) ion pairing reagent flowing at 0.5 $\mathrm{mL} / \mathrm{min}$. The conditions used were an attempt to achieve resolution of both the $\mathrm{Na}_{2}{ }^{10} \mathrm{BSH}$ parent component and $\mathrm{B}_{12} \mathrm{H}_{12}{ }^{-2}$.

The chromatographic results for the two shipments from Boron Biologicals are listed in Table 3. Displayed in Figure 4 are sample chromatograms of BNCT 473, and the reference sample BNCT 202. Figure 5 displays the sample chromatograms of BNCT 477 and BNCT 529. The reference sample (BNCT 202) is prepared as an individual sample, whereas the test samples are prepared in triplicate. Duplicate chromatograms are acquired for all of the standards and test samples. The HPLC analyses indicated that all of the new BSH materials are a relatively clean with regards to the presence of BSS and BSSO. Sample BNCT 477 had no detectable dimer species, however, the 
presence of some oxidation products was noted in BNCT 529 and 473. The presence of late eluting peaks was apparent in samples BNCT 473, 477 and 529. At this time, the identity of these peaks has still not been determined. Proton NMR analyses indicated the presence of an organic species. However, the compound was not identified by HPLC. Under the given HPLC conditions the analyses were still inconclusive regarding the presence of the $\mathrm{B}_{12} \mathrm{H}_{12}{ }^{-2}$.

ICP-AES Analysis: Elemental analysis for $B, S$, and $\mathrm{Na}$ by ICP-AES were preformed on aliquots of all samples and standards prepared for HPLC. The results of these analyses are presented in Table 4. The weight percent of $B, S$, and $\mathrm{Na}$ for many of the samples indicated a slight over recovery, probably due to handling errors in weighing $\mathrm{mg}$ quantities of the samples vials tared on a balance external to the glove bag where the samples are handled. In any case, the calculated mole ratios are unaffected by weighing/preparation errors. Boron appears to be consistently over recovered. The BNCT 477 sample appears to be slightly low in sodium.

CHN Combustion Analysis: A nitrogen atmosphere was utilized as much as possible for preparation of the samples use in the combustion analyses. The results are presented in Table 5. Sulfur results are not reported since they are not reproducible and usually low. The $\% \mathrm{C}$ value appears higher than normal in the BNCT 529 sample. This sample also showed a small impurity when analyzed by proton NMR. The sample had significant "late-eluting" peaks in the HPLC chromatogram.

NMR Spectroscopy: The "B NMR of BNCT 529 had a poor signal-to-noise ratio. The ${ }^{10} \mathrm{~B}$ NMR signal-to-noise ratio indicated that BNCT 529 was definitely ${ }^{10} \mathrm{BSH}$ and that $\mathrm{BSH}$ was the primary constituent. The 'H NMR indicated that BNCT 529 may contain a small quantity of in Urirdentified organic species. The 'H NMR is shown in Figure 6 . The sample was dissolved in $\mathrm{D}_{2} \mathrm{O}$. The peaks at $\delta 4.3-4.8 \mathrm{ppm}$ is due the $\mathrm{H}_{2} \mathrm{O}$ and $\mathrm{HOD}$ in the $\mathrm{D}_{2} \mathrm{O}$. The peaks of concern are the multiplet at $\sim \delta 2.1 \mathrm{ppm}$ and the low intensity peaks near $\delta 7 \mathrm{ppm}$. The pyrrolidone intermediate did not match the spectrum of the unknown component(s). Since the carbon content was under $1 \%$, the impurity was not considered excessive. Because of some unexpected problems with the instrumentation, NMR was not performed on the remaining samples.

FTIR Spectroscopy: Due to unexpected instrumentai probiems the samples were not analyzed by FIIR at this time.

Task 3: Intra- and Intercellular Boron Analyses

No progress to report.

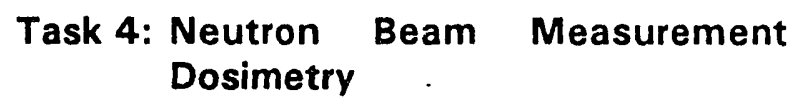

Oregon State University:

Further work on the ORSU reactor thermal column shielding has reduced the gamma ray dose to thermal neutron fluence ratio to $2 \times 10^{-11}$ $\mathrm{cGy} r /\left(\mathrm{n} / \mathrm{cm}^{2}\right)$ with the bismuth sample holder in place. A thermal neutron fluence of $10^{13} \mathrm{n}$ $\mathrm{cm}^{-2}$ can be attained in a four minute irradiation at full power. This shielding geometry is now being used for all BNCT irradiations in the ORSU reactor thermal column.

Preliminary planning and scoping studies have begun to evaluate the ORSU reactor thermal column as an in vivo irradiation facility for rats. A thermal neutron fluence of $10^{11} \mathrm{n}-\mathrm{cm}^{-2}$ has been attained in a ten minute irradiation with a gamma ray dose to thermal neutron fluence ratio of $6 \times 10^{-11} \mathrm{cGy} y /\left(\mathrm{n} / \mathrm{cm}^{2}\right)$. These values were obtained as a first cut experiment without any attempt at optimizing either value.

A significant thermal neutron effect on thermolumirescent dosimeter (TLD)-400 $\left(\mathrm{CaF}_{2}: \mathrm{Mn}\right)$ has been noticed. During irradiation in a mixed neutron and gamma ray field, a sizeable portion of the thermoluminescence (up to about half in our investigations) can be contributed by the thermal neutron activation of manganese and the subsequent deposition of energy in the TLD chip. Details will be discussed at the March 1993 INEL BNCT Planning Meeting.

The ORSU College of Oceanography inductively coupled plasma-mass spectrometry (ICP-MS) system has been used for some preliminary boron measurements. Calibrations indicate a lower limit of detection capability of this system for boron of about $0.1 \mathrm{ppb}$. Some boron 
Table 3. Oxidation products in BNCT 473, BNCT 477, BNCT 529 and the reference sample (BNCT 202) as determined by HPLC.

\begin{tabular}{cccc}
\hline Sample & Compound & BSS $^{4 \cdot}$ (wt \%) & BSSO $^{4 \cdot}$ (wt \%) \\
\hline 202 & $\mathrm{Na}_{2} \mathrm{~B}_{12} \mathrm{H}_{11} \mathrm{SH}$ & $1.56 \pm 0.03$ & $0.23 \pm 0.02$ \\
473 & $\mathrm{Na}_{2}{ }^{10} \mathrm{~B}_{12} \mathrm{H}_{1} \mathrm{SH}$ & $0.29 \pm 0.11$ & $\mathrm{ND}$ \\
477 & $\mathrm{Na}_{2} \mathrm{~B}_{12} \mathrm{H}_{11} \mathrm{SH}$ & $\mathrm{ND}$ & $\mathrm{ND}$ \\
529 & $\mathrm{Na}_{2}{ }^{10} \mathrm{~B}_{12} \mathrm{H}_{11} \mathrm{SH}$ & $0.36 \pm 0.08$ & $0.017 \pm 0.004$ \\
\hline
\end{tabular}

Table 4. ICP-AES analysis of BSH compounds.

\begin{tabular}{|c|c|c|c|c|c|c|c|}
\hline \multirow[b]{2}{*}{ Sample } & \multirow[b]{2}{*}{ Compound } & \multirow[b]{2}{*}{ wt\% s } & \multirow[b]{2}{*}{$w t \% B^{*}$} & \multirow[b]{2}{*}{ wt\% $\mathrm{Na}$} & \multicolumn{3}{|c|}{ Mole Ratios } \\
\hline & & & & & $B / S$ & $\mathrm{~B} / \mathrm{Na}$ & $\mathrm{Na} / \mathrm{S}$ \\
\hline 202 & $\mathrm{Na}_{2} \mathrm{~B}_{12} \mathrm{H}_{1}, \mathrm{SH}$ & 11.49 & 51.93 & 16.12 & 13.73 & 7.02 & 1.96 \\
\hline 210 & 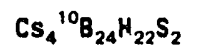 & 7.34 & 30.25 & 0 & 13.13 & & \\
\hline 212 & $\mathrm{Cs}_{4}{ }^{10} \mathrm{~B}_{24} \mathrm{H}_{22} \mathrm{~S}_{2}$ & 8.43 & 36.66 & 0 & 13.72 & & \\
\hline $473 A$ & $\mathrm{Na}_{2}{ }^{10} \mathrm{~B}_{12} \mathrm{H}_{11} \mathrm{SH}$ & 13.38 & 56.85 & 21.70 & 12.5 & 5.79 & 2.16 \\
\hline $473 B$ & $\mathrm{Na}_{2}{ }^{10} \mathrm{~B}_{12} \mathrm{H}_{1}, \mathrm{SH}$ & 14.05 & 57.72 & 22.32 & 13.41 & 5.83 & 2.27 \\
\hline $473 c$ & $\mathrm{Na}_{2}{ }^{10} \mathrm{~B}_{12} \mathrm{H}_{1}, \mathrm{SH}$ & 13.17 & 57.52 & 22.32 & 13.67 & 5.83 & 2.34 \\
\hline $477 \mathrm{~A}$ & $\mathrm{Na}_{2} \mathrm{~B}_{12} \mathrm{H}_{1}, \mathrm{SH}$ & 12.71 & 60.11 & 17.77 & $14: 19$ & 7.28 & 1.95 \\
\hline 4778 & $\mathrm{Na}_{2} \mathrm{~B}_{12} \mathrm{H}_{1}, \mathrm{SH}$ & 14.49 & 66.11 & 19.04 & 13.74 & 7.50 & 1.83 \\
\hline $477 C$ & $\mathrm{Na}_{2} \mathrm{~B}_{12} \mathrm{H}_{1}, \mathrm{SH}$ & 14.16 & 65.08 & 19.12 & 13.84 & 7.35 & 1.88 \\
\hline $529 \mathrm{~A}$ & $\mathrm{Na}_{2}{ }^{10} \mathrm{~B}_{12} \mathrm{H}_{1}, \mathrm{SH}$ & 14.90 & 60.40 & 22.32 & 12.99 & 6.22 & 2.09 \\
\hline 5298 & $\mathrm{Na}_{2}{ }^{10} \mathrm{~B}_{12} \mathrm{H}_{1}, \mathrm{SH}$ & 14.80 & 61.12 & 20.89 & 13.14 & 6.68 & 1.97 \\
\hline $529 \mathrm{C}$ & $\mathrm{Na}_{2}{ }^{10} \mathrm{~B}_{12} \mathrm{H}_{1}, \mathrm{SH}$ & 15.31 & 60.17 & 20.82 & 12.53 & 6.61 & 1.90 \\
\hline
\end{tabular}

Table 5. CHN combustion analysis results.

\begin{tabular}{cccc}
\hline Sample & $w t \% \mathrm{C}$ & wt\% & wt\% N \\
\hline $202^{\circ}$ & $0.81 \pm 0.11$ & $6.27 \pm 0.04$ & 0 \\
473 & $0.61 \pm 0.10$ & $6.02 \pm 0.06$ & 0 \\
477 & $0.55 \pm 0.03$ & $6.25 \pm 0.18$ & 0 \\
529 & $0.94 \pm 0.03$ & $5.77 \pm 0.05$ & 0 \\
Expected & & 5.5 & \\
\hline 202 stock vial previous analysis October 1992. & & \\
\hline
\end{tabular}




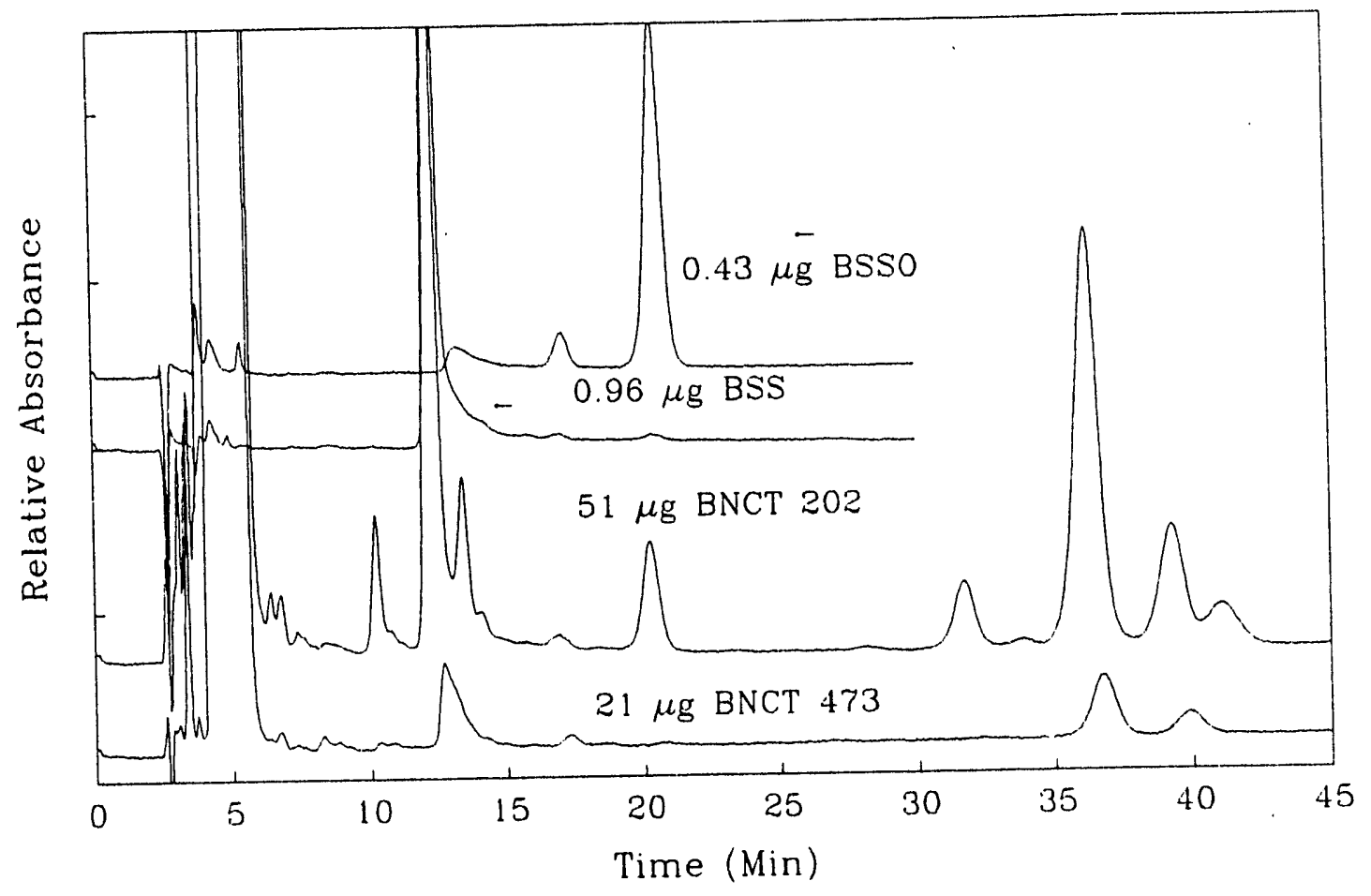

Figure 4. Reversed phase, ion pair HPLC chromatograms of the new samples (BNCT 473), the reference sample (BNCT 202) and standards of $\mathrm{BSS}^{4 \cdot}$ and $\mathrm{BSSO}^{4}$.

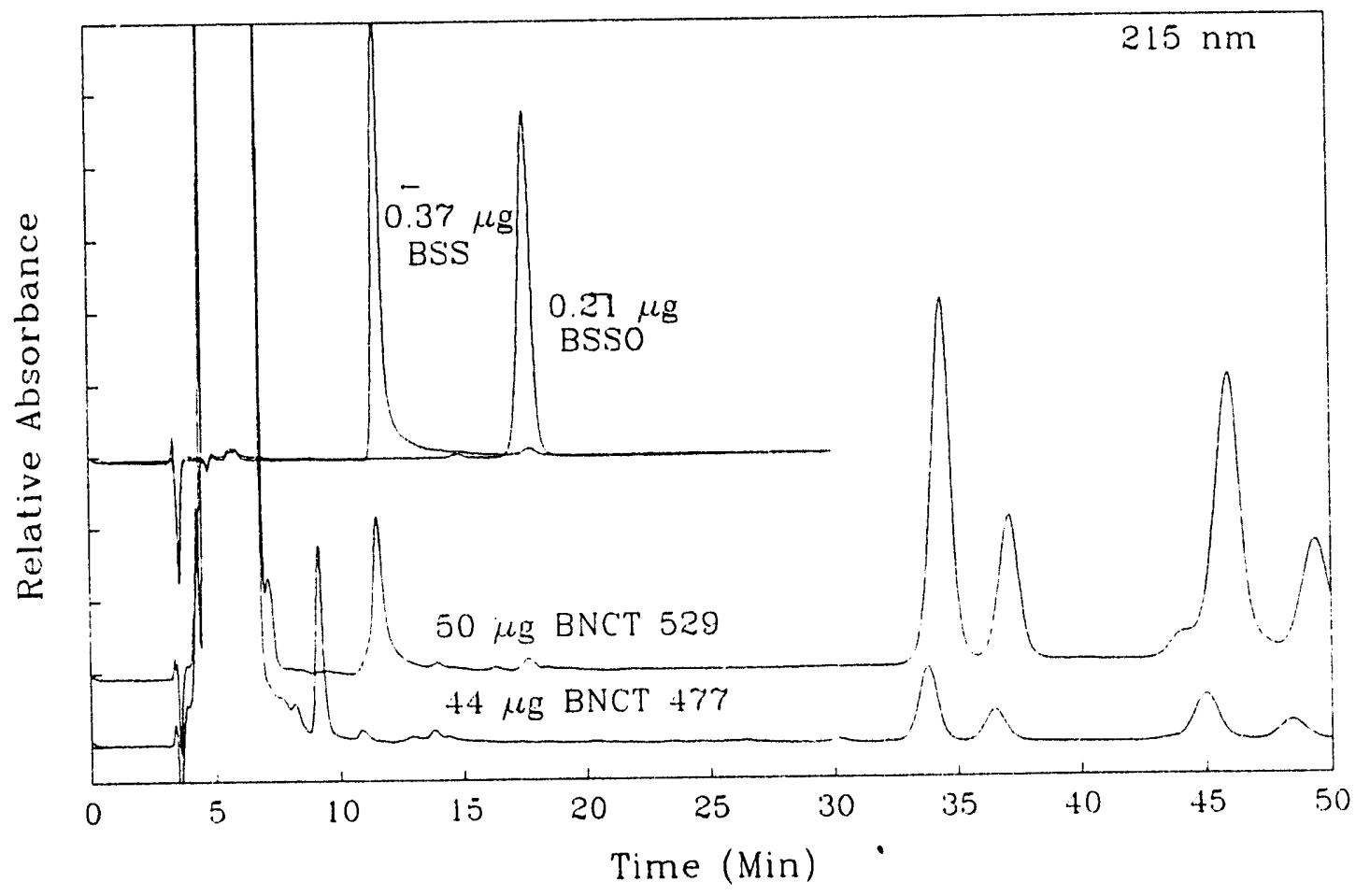

Figure 5. Reversed phase ion pair HPLC chromatograms of the Boron Biological samples BNCT 477, BNCT 529 and standards of BSS $^{4 \cdot}$ and BSSO ${ }^{4 .}$. 


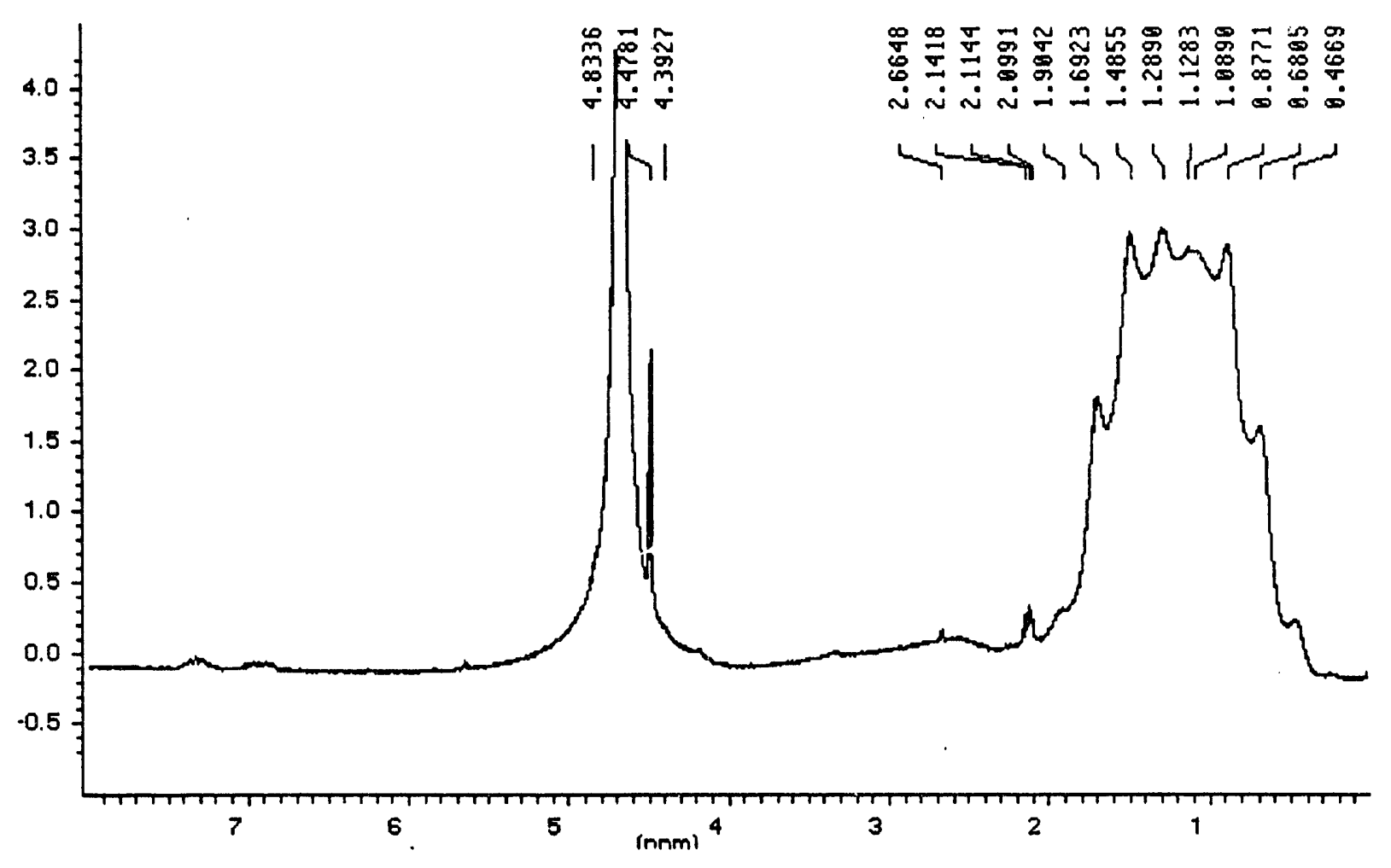

Figure 6. ' $\mathrm{H}$ NMR of BNCT 529 in $\mathrm{D}_{2} \mathrm{O}$.

analyses of cells have been conducted with concentrations in the few ppb range. The ICP. MS system is sensitive to boron "sticking" in the system. At present, analyses on this system have been curtailed because of technical and funding issues to be worked out.

\section{BMRR:}

During January 26-28, 1993 neutron flux measurements were made at the BMRR filtered beam port in the Labrador head-phantom. These measurements were made using the 10 $x 10 \mathrm{~cm}$ aperture centered on the head, and with the $5 \times 10 \mathrm{~cm}$ mask aperture on the right hemisphere. The purpose was to confirm the values of neutron fluxes to be expected for treatment dogs $(10 \times 10 \mathrm{~cm}$ aperture $)$, and dosetolerance dogs $(5 \times 10 \mathrm{~cm}$ aperture $)$ after the July 1992 reactor fuel movement.

Figure 7 shows the thermal and Figure 8 the epithermal flux values as a function of depth into the phantom for the $10 \times 10 \mathrm{~cm}$ aperture.
A repeat of two of the free-field neutron spectrum foil measurements, originally made in November 1992, was performed for copper and copper-manganese foils. The purpose of the repeat measurement was to remove large edge effects on these foils by surrounding them with a ring of the same matesial. Such rings had not been used in November, and only a rough estimate of a correction for the effect could be made. The new measurements made a significant improvement in the spectrum. Figure 9 shows a plot of this spectrum. Using this spectrum, the flux increase due to moving and adding fuel at BMRR in 1992, compared to before the movement, was determined to be a factor of 1.49. BMRR's free-field measurements; i.e. without a mask, indicates a factor of 1.52, which is in reasonable agreement.

During this same period researchers at BNL made measurements in the plastic ellipsoidal phantom containing both INEL (gold-copper) and BNL (gold) neutron flux foils. These were done at the epithermal-neutron port without the use of a mask aperture. INEL personnel ana- 


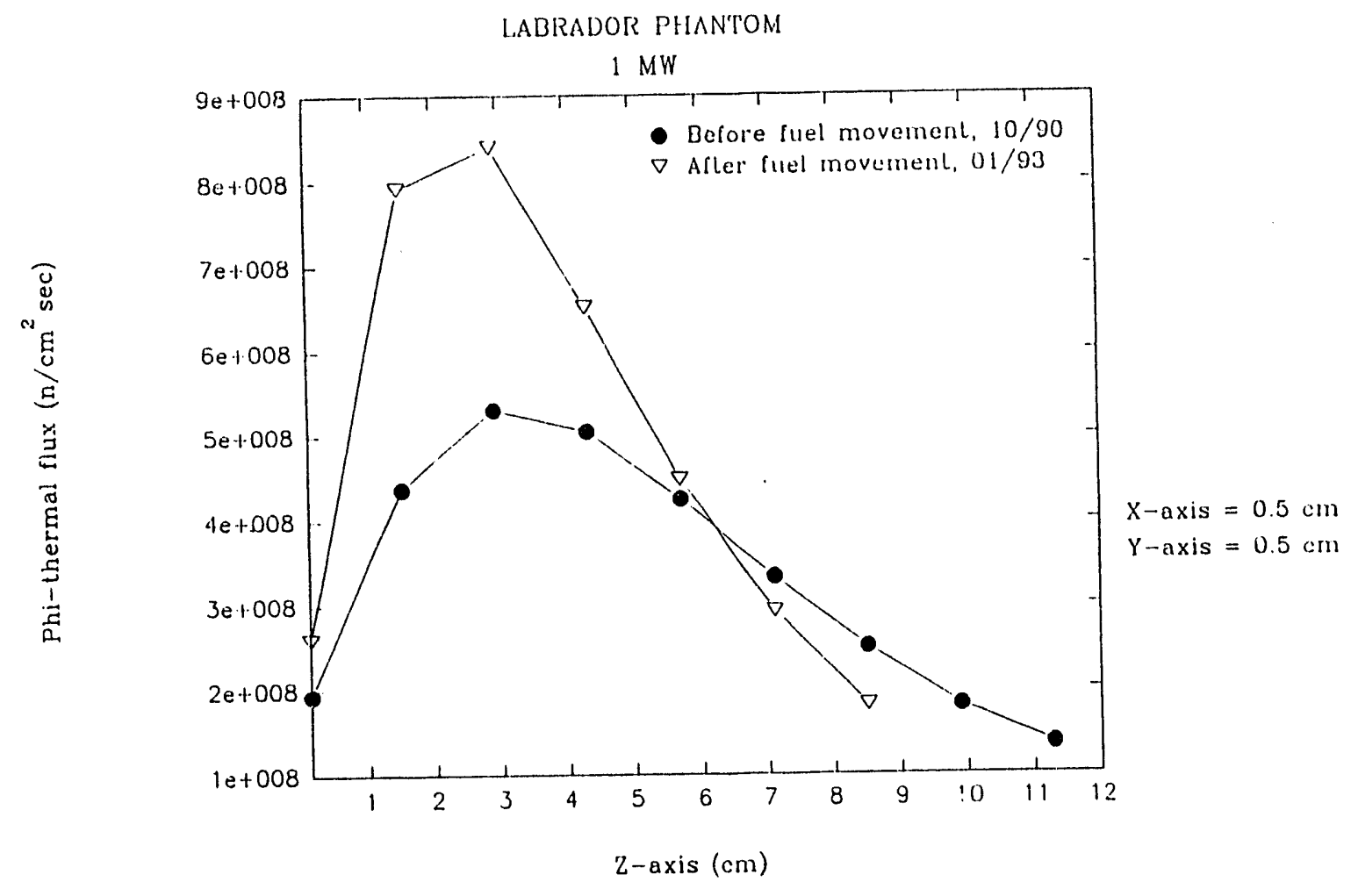

Figure 7. BMRR: Thermal flux values as a function of depth.

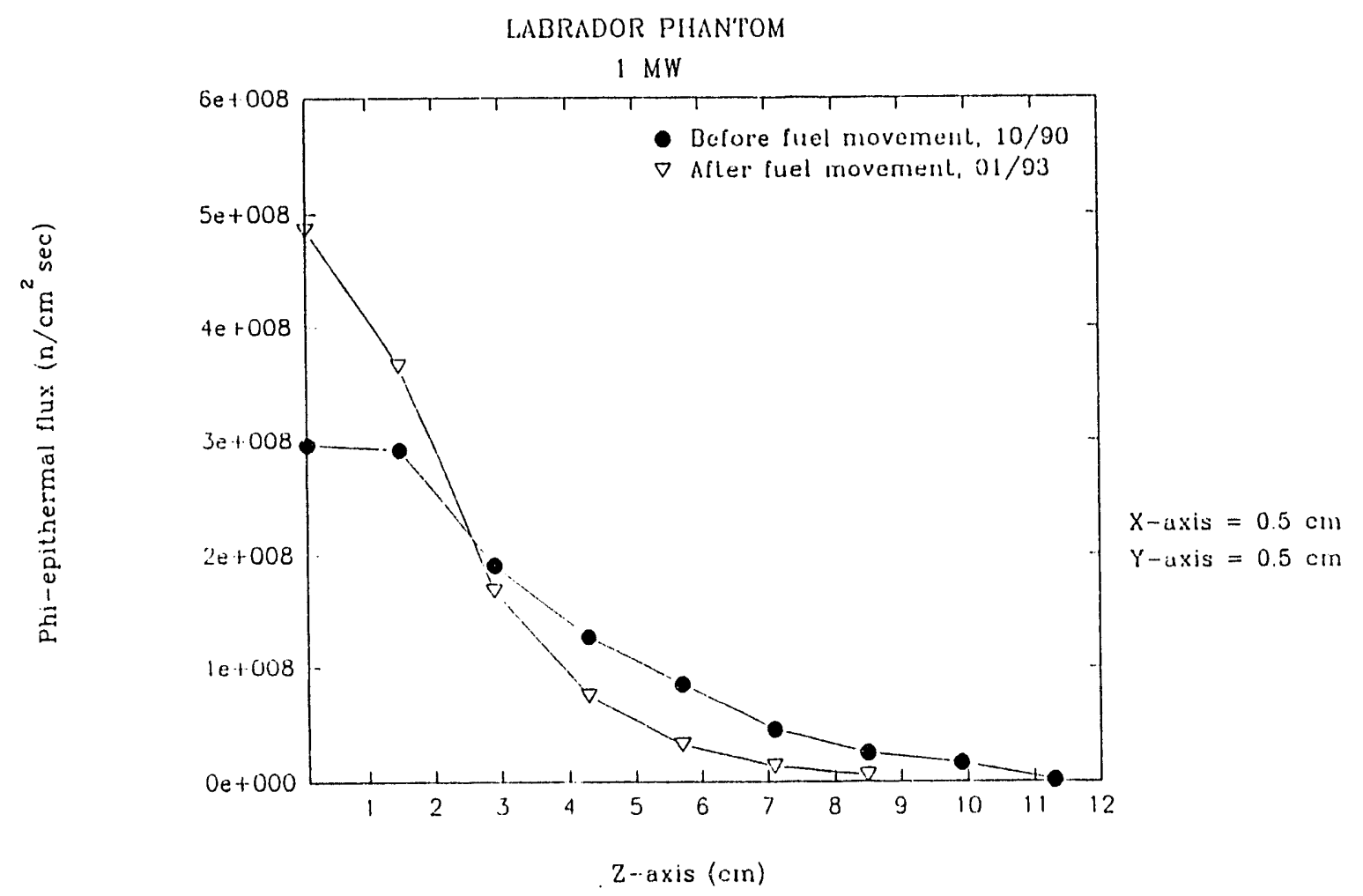

Figure 8. BMRR: Epithermal flux values as a function of depth. 


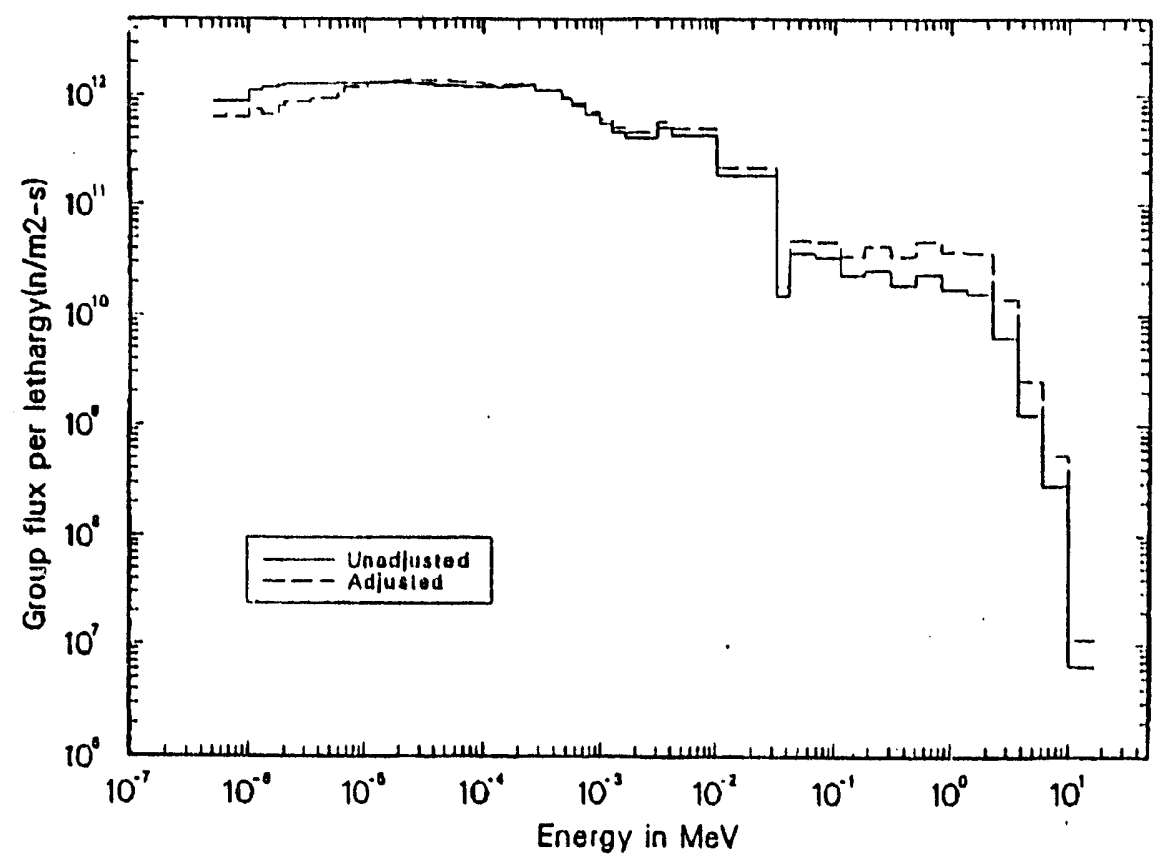

Figure 9. BMRR: Free field neutron spectrum foil measurement.

lyzed the gold-copper foils, and BNL the gold foils. Figure 10 shows the plot of the thermal and epithermal- neutron fluxe as a function of distance into the phantom, together with the three-dimensional Monte Carlo computer code (MCNP) calculation results. The measurements are in good agreement with each other, and with the calculations. Measurements of gamma doses in this phantom were also made using both TLD-700 rods (which are used by BNL and read out on their reader), and TLD-400 rods (which are used by INEL and read out at INEL). A comparison indicates that the TLD700 doses agree with both BNL and INEL gamma dose calculations, but the TLD-400 rods indicate only about half as much dose. The cause of this discrepancy is being examined.

During February 8-12, 1993 five dose-tolerance Labrador Retrievers were infused with $\mathrm{BSH}$ drug and irradiated, and five Beagles, infused with BPA, were irradiated by BNL. INEL provided the dosimetry for Beagles. These were all irradiated at the epithermal beam port using the
$5 \times 10 \mathrm{~cm}$ mask aperture for all dogs. For the Labradors, the usual right hemisphere irradiation was done. A Beagle has a smaller skull than a Labrador, and a right-hemisphere irradiation would have placed the edge of the irradiation table partially in the beam. Therefore, for these dogs a left-hemisphere irradiation was used. The data are being analyzed.

\section{Task 5: Canine Dosimetry Calculations}

No progress to report.

\section{Task 6: BNCT Database Management System}

Database development and data entry continue at WSU.

\section{Task 7: Georgia Tech Research Reactor Physics Support}

No progress to report. 


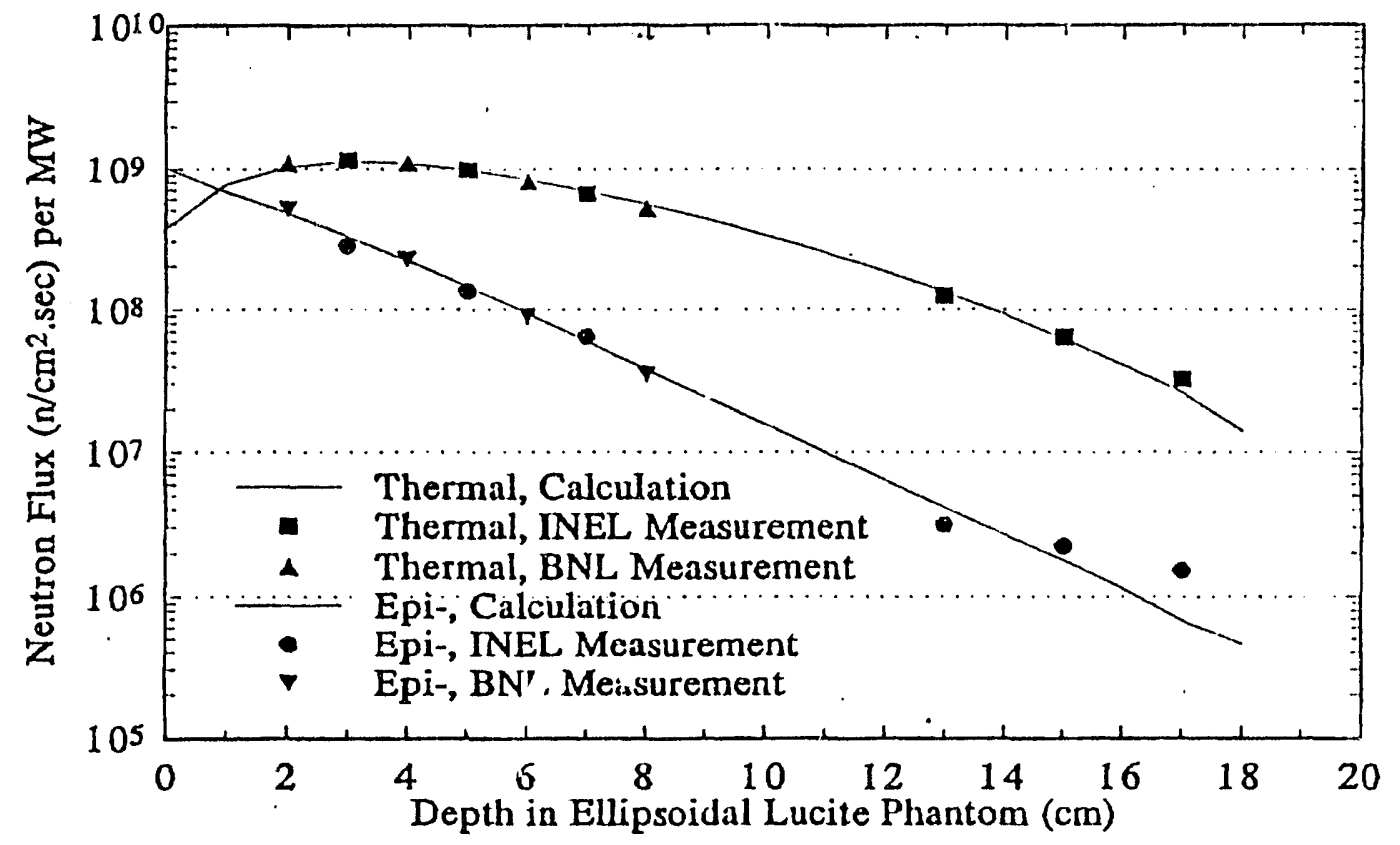

Figure 10. BMRR: Thermal and epithermal-neutron fluxes as a function of distance in phantom.

\section{Task 8: Research Reactor/Accelerator Physics Support}

BMRR Fuel Reconfiguration: Prior to the summer of 1992, the design and as-built analytical physics models for the INEL epithermal-neutron filter and BMRR core were based on the assumption of homogenous fuel and $r z$ geometry. In these models, the $z$ axis was everywhere coincident with the center line of the epithermal 'beam', necessitating the representation of core geometry as a cylinder lying on its side. This model has worked quite nicely since the beam characteristics were not greatly sensitive to the detailed source (fission) neutron distributions so long as the gross source profiles were similar to a chopped cosine distribution.

In 1992, however, BNL reconfigured the core, adding fuel and placing highly loaded elements on the east, toward the epithermal filter, to increase the intensity of the epithermal beam. Graphite filter elements on the east side were replaced with the high load fuel elements. This reconfiguration results in a highly skewed power distribution which cannot be calculated with the $r z$ geometry. Therefore, a new model, based on xy core geometry and discrete fuelelement representation has been developed and analyses have been performed to predict characteristics for both the epithermal (east) and thermal (west) beams.

Figure 11 shows the fuel-element distributions in the reconfigured (present) core and Table 6 provides the new fuel-element inventories as specified by BNL personnel.

Complete calculations were then performed for the core and the epithermal and thermal filters to compare with measurements and provide validated beam specification for use in the animal irradiations program.

Results for the free field and phantom measurements comparisons were similar to those obtained for the original configuration even though the model was quite different. The unnormalized free-field flux intensity was within 


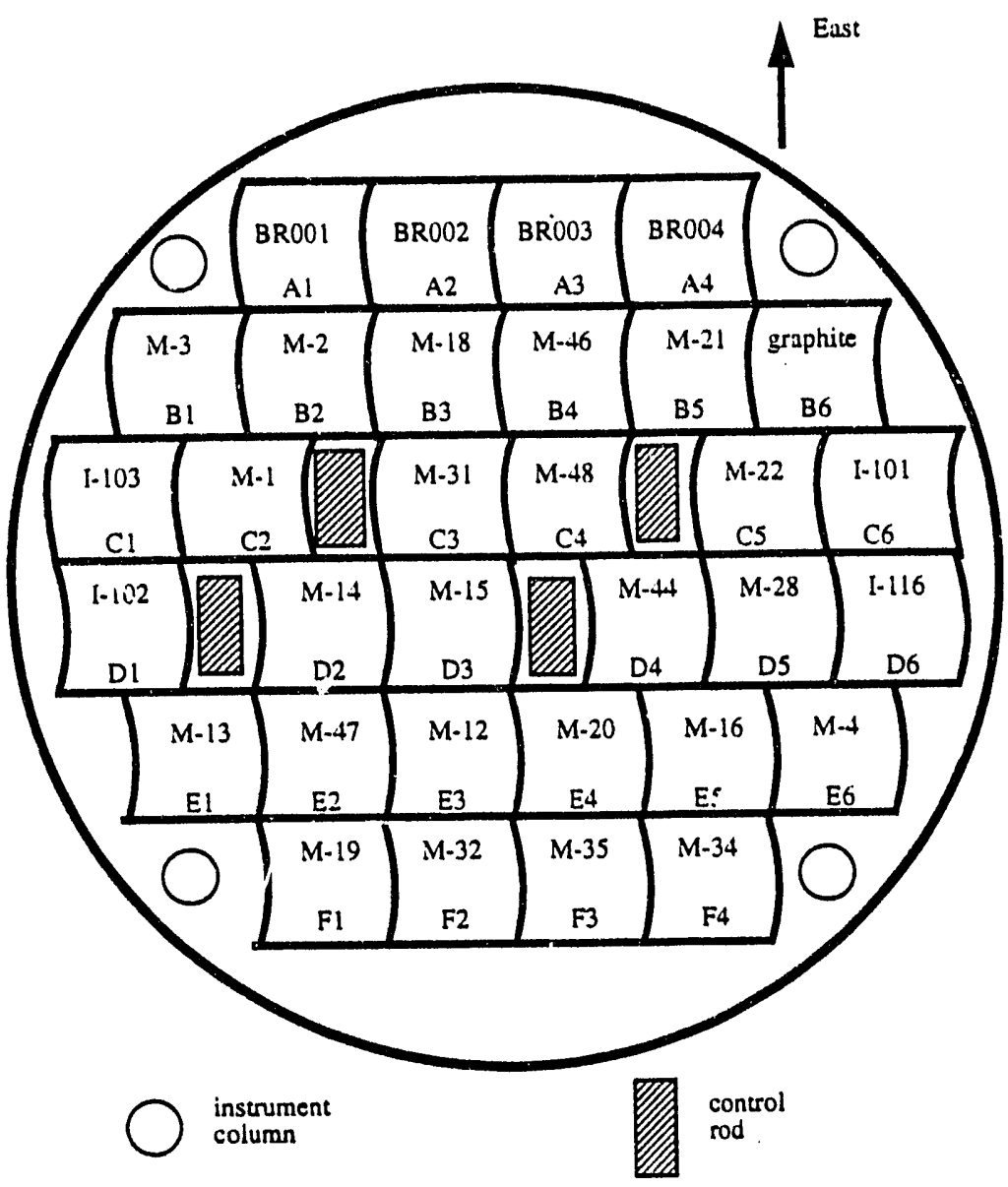

Figure 11. Fuel element locations for the reconfigured BMRR core.

unnormalized free-field flux intensity was within $5 \%$ of the measured intensity but the calculated fast flux was $30-40 \%$ low as before due to known limitations of the analytical model. The free-field intensity was predicted to have increased by about $50 \%$, but the restricted beam (with delimiter in place) generated thermal flux intensities only about $30 \%$ higher than for the original beam. This is thought to be due to changes in the angular and spatial dependence of the beam because of the change in the core configuration.

Figure 12 shows the neutron spectrum for the epithermal beam (adjusted in the high-energy region by measured results), and Figure 13 shows unadjusted calculations and measurements for a $12.7-\mathrm{cm}$ diameter by $18.1-\mathrm{cm}$ long Lucite cylinder for the original core configuration and for the newly-reconfigured core. Other comparisons with the Lucite dog-head phantom and the BNL ellipsoidal phantom show similar results.

\section{Miscellaneous:}

\section{Publications:}

"Selective Brain Tumor Ablation by Boron Neutron Capture Therapy," J. Coderre, P. Rubin, A. Freedman, J. Hanson, T. Wooding, Jr., D. Joel, and D. Gash.

"Boron Neutron Capture Therapy - A Truly Selective Form of Radiation Treatment in Malignant Brain Tumors," P. Rubin, J. Coderre, D. Gash, A. Freedman, and J. Hansen.

"Early and Persistent Disruptions of BloodBrain-Barrier After Photon Irradiation, " D. Gash, $P$. Rubin, and $A$. Freedman. 
Table 6. BMRR fuel inventory as of July 7, 1992.

\begin{tabular}{|c|c|c|c|c|c|c|c|c|}
\hline El ement & Core Loc & Position & Initial & Initial & Present & Present & $\%$ Fiss U & $\%{ }^{235} \mathrm{U}$ \\
\hline BR001 & A1 & 0.35 & 149.58 & $139.3^{\prime}$ & 147.59 & 137.00 & 1.33 & 1.68 \\
\hline BR002 & $A 2$ & 0.49 & 149.00 & 139.00 & 149.00 & 139.00 & 0.00 & 0.00 \\
\hline BR003 & A3 & 0.50 & 149.00 & 139.00 & 149.00 & 139.00 & 0.00 & 0.00 \\
\hline BR004 & A4 & 0.38 & 149.00 & 139.00 & 149.00 & 139.00 & 0.00 & 0.00 \\
\hline$M-3$ & B1 & 0.28 & 149.50 & 139.24 & 123.64 & 108.82 & 17.29 & 21.85 \\
\hline$M-2$ & $\mathrm{B2}$ & 0.60 & 150.67 & 140.38 & 121.04 & 105.41 & 19.67 & 24.91 \\
\hline$M-18$ & 83 & 0.79 & 150.95 & 140.52 & 116.95 & 100.49 & 22.52 & 28.49 \\
\hline$M-46$ & 84 & 0.80 & 150.70 & 140.34 & 126.37 & 111.75 & 16.15 & 20.37 \\
\hline$M-21$ & $B 5$ & 0.64 & 150.98 & 140.68 & 130.20 & $\$ 16.26$ & 13.76 & 17.36 \\
\hline GRPH & $B 6$ & 0.34 & 0.0 & 0.0 & 0.0 & 0.0 & 0.0 & 0.0 \\
\hline $1 \cdot 103$ & c1 & 0.20 & 214.79 & 192.40 & 208.01 & 184.43 & 3.16 & 4.14 \\
\hline$M-1$ & $\mathrm{C2}$ & 0.60 & 150.37 & 140.11 & 116.90 & 100.69 & 22.26 & 28.14 \\
\hline$M-31$ & C3 & 0.94 & 150.14 & 139.86 & 130.45 & 116.72 & 13.11 & 16.54 \\
\hline$M-48$ & $\mathrm{C4}$ & 0.96 & 151.05 & 140.62 & 133.12 & 119.55 & 11.87 & 14.98 \\
\hline$M-22$ & C5 & 0.65 & 150.69 & 140.36 & 124.31 & 109.36 & 17.50 & 22.08 \\
\hline $1-101$ & C6 & 0.31 & 212.82 & 190.66 & 205.59 & 182.16 & 3.40 & 4.46 \\
\hline $1-102$ & 01 & 0.31 & 212.96 & 190.78 & 206.44 & 183.12 & 3.06 & 4.02 \\
\hline$M-14$ & $D 2$ & 0.80 & 150.52 & 140.18 & 118.65 & 102.63 & 21.17 & 26.79 \\
\hline$M-15$ & 03 & 0.96 & 150.70 & 139.91 & 117.78 & 101.71 & 21.85 & 27.31 \\
\hline$M-44$ & 04 & 0.88 & 150.55 & 140.18 & 125.02 & 110.18 & 16.96 & 21.40 \\
\hline$M-28$ & D5 & 0.60 & 149.74 & 139.45 & 124.30 & 109.55 & 16.99 & 21.44 \\
\hline $1 \cdot 116$ & 06 & 0.26 & 214.42 & 192.09 & 208.35 & 184.96 & 2.83 & 3.71 \\
\hline$M-13$ & E1 & 0.34 & 150.36 & 140.05 & 118.44 & 102.44 & 21.23 & 26.86 \\
\hline$M-47$ & E2 & 0.64 & 150.87 & 140.46 & 126.40 & 111.70 & 16.22 & 20.47 \\
\hline$M-12$ & E3 & 0.40 & 150.25 & 139.97 & 119.04 & 103.19 & 20.77 & 26.28 \\
\hline$M-20$ & E4 & 0.79 & 150.74 & 140.46 & 128.64 & 114.46 & 14.66 & 18.51 \\
\hline$M-16$ & E5 & 0.60 & 150.17 & 139.88 & 116.69 & 100.46 & 22.29 & 28.18 \\
\hline$M-4$ & E6 & 0.28 & 149.97 & 139.71 & 118.37 & 102.45 & 21.07 & 26.67 \\
\hline$M-19$ & $F 1$ & 0.38 & 150.62 & 140.26 & 128.23 & 113.87 & 14.87 & 18.82 \\
\hline$M-32$ & F2 & 0.50 & 150.41 & 140.08 & 130.85 & 117.10 & 13.00 & 16.41 \\
\hline$M-35$ & F3 & 0.49 & 150.44 & 140.12 & 134.12 & 120.94 & 10.85 & 13.69 \\
\hline$M \cdot 34$ & $F 4$ & 0.35 & 150.43 & 140.12 & 130.12 & 116.25 & 13.50 & 17.03 \\
\hline
\end{tabular}



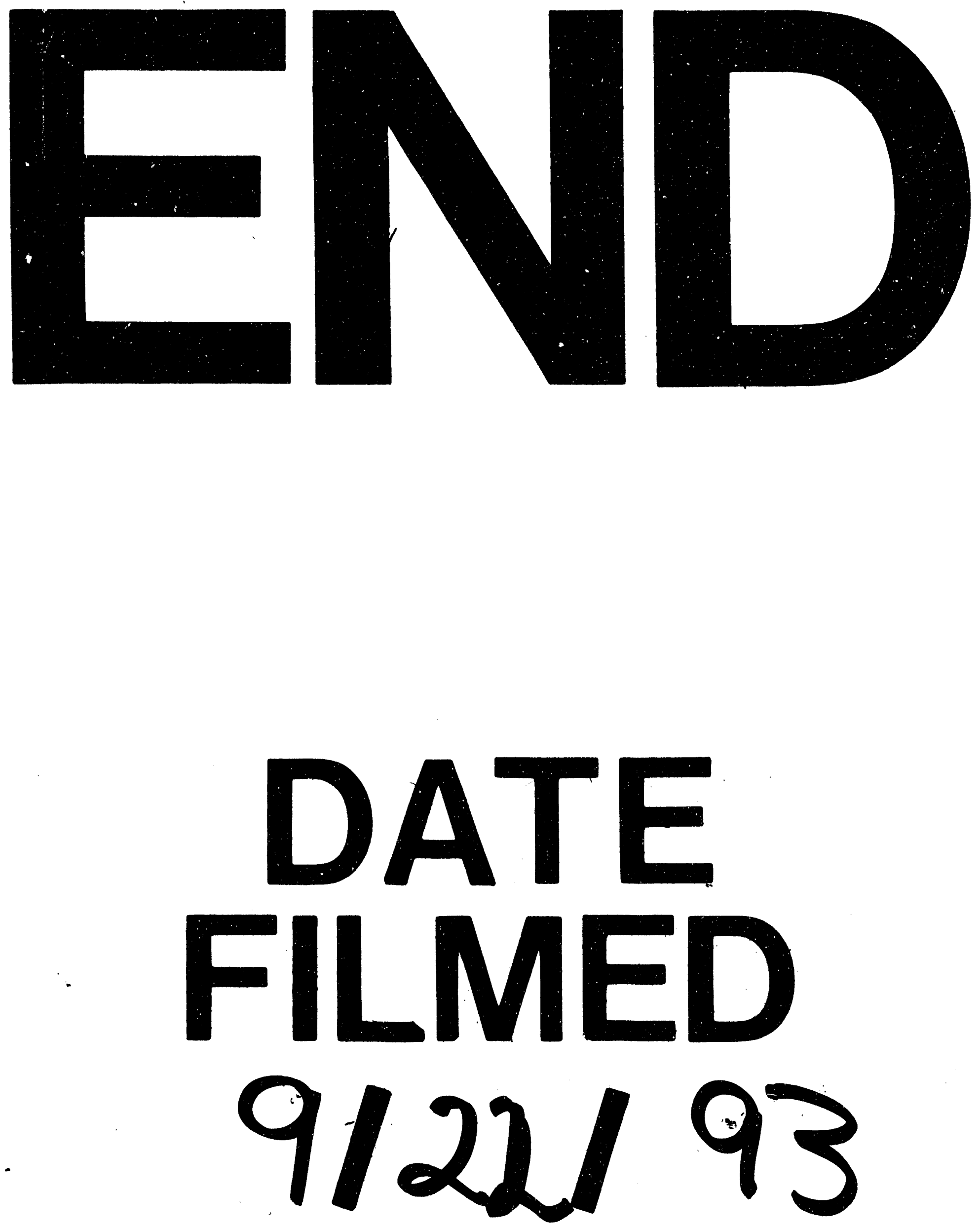
